\title{
Expanding the utilization of sustainable plant products in aquafeeds: a review
}

\author{
Delbert M Gatlin III ${ }^{1}$, Frederic T Barrows ${ }^{2}$, Paul Brown ${ }^{3}$, Konrad Dabrowski ${ }^{4}$, T Gibson Gaylord $^{1}$, \\ Ronald W Hardy ${ }^{5}$, Eliot Herman ${ }^{6}$, Gongshe Hu${ }^{7}$, Åshild Krogdahl ${ }^{8}$, Richard Nelson', \\ Kenneth Overturf ${ }^{1}$, Michael Rust ${ }^{10}$, Wendy Sealey ${ }^{5}$, Denise Skonberg ${ }^{11}$, Edward J Souza ${ }^{7}$, \\ David Stone ${ }^{5}$, Rich Wilson ${ }^{9}$ \& Eve Wurtele ${ }^{12}$ \\ ${ }^{1}$ Texas A\&M University System, College Station,TX, USA \\ ${ }^{2}$ USDA/ARS Hagerman Fish Culture Experiment Station, Hagerman, ID, USA \\ ${ }^{3}$ Purdue University, West Lafayette, IN, USA \\ ${ }^{4}$ The Ohio State University, Columbus, OH, USA \\ ${ }^{5}$ Hagerman Fish Culture Experiment Station, Hagerman, ID, USA \\ ${ }^{6}$ USDA/ARS - Donald Danforth Plant Science Center, St Louis, MO, USA \\ ${ }^{7}$ USDA/ARS, Washington, DC, USA \\ ${ }^{8}$ Aquaculture Protein Centre, Ås, Norway \\ ${ }^{9}$ Nelson \& Sons, Murray, UT, USA \\ ${ }^{10}$ NOAA Northwest Fisheries Science Center, Seattle,WA, USA \\ ${ }^{11}$ University of Maine, Orono, ME, USA \\ ${ }^{12}$ Iowa State University, Ames, IA, USA
}

Correspondence: D M Gatlin III, Department of Wildlife and Fisheries Sciences, 2258 TAMUS, College Station, TX 77843-2258, USA. E-mail: d-gatlin@tamu.edu

Gatlin and Barrows are Chair and Vice-chair, respectively, of the Plant Products in Aquafeeds Working Group, and coordinated the development of this document; all other authors are listed in alphabetical order.

\section{Abstract}

Continued growth and intensification of aquaculture production depends upon the development of sustainable protein sources to replace fish meal in aquafeeds. This document reviews various plant feedstuffs, which currently are or potentially may be incorporated into aquafeeds to support the sustainable production of various fish species in aquaculture. The plant feedstuffs considered include oilseeds, legumes and cereal grains, which traditionally have been used as protein or energy concentrates as well as novel products developed through various processing technologies. The nutritional composition of these various feedstuffs are considered along with the presence of any bioactive compounds that may positively or negatively affect the target organism. Lipid composition of these feedstuffs is not specifically considered although it is recognized that incorporating lipid supplements in aquafeeds to achieve proper fatty acid profiles to meet the metabolic requirements of fish and maximize human health benefits are important aspects. Specific strategies and techniques to optimize the nutritional composition of plant feedstuffs and limit potentially adverse effects of bioactive compounds are also described. Such information will provide a foundation for developing strategic research plans for increasing the use of plant feedstuffs in aquaculture to reduce dependence of animal feedstuffs and thereby enhance the sustainability of aquaculture.

Keywords: alternative proteins, sustainable aquafeeds, plant proteins

\section{Introduction/justification for increased use of plant products in aquaculture}

According to the UN Food and Agriculture Organization, aquaculture is growing more rapidly than all other animal food-production sectors (FAO. State of world aquaculture 2006). Its contribution to global supplies of fish, crustaceans and molluscs increased from $3.9 \%$ of total production by weight in 1970 to $33 \%$ in 2005 . This growth is at an average 
compounded rate of $9.2 \%$ per year since 1970 , compared with only $1.4 \%$ for capture fisheries and $2.8 \%$ for terrestrial farmed-meat production systems. It is remarkable that one out of every three fish consumed in the world is now farm raised.

The expansion of aquaculture production has been accompanied by rapid growth of aquafeed production. The challenge facing the aquaculture industry is to identify economically viable and environmentally friendly alternatives to fish meal and fish oil on which many present aquafeeds are largely based. While the supply of fish meal and oil is arguably sustainable, the anticipated growth in demand internationally for use in aquafeeds is expected to exceed the supply in the next decade. Thus, the aquafeeds industry has recognized for many years that viable utilization of plant feedstuffs formulated in aquafeeds for the production of cold, cool and warmwater aquatic species is an essential requirement for future development of aquaculture. Such plant feedstuffs must provide nutritious diets that will effectively grow aquatic species with minimal environmental impact and produce high-quality fish flesh to confer human health benefits in a cost-effective manner. As the aquaculture industry continues to expand on a global scale, access to key feedstuffs, such as fish meal and oil, will become increasingly limited because of a finite wild-harvest resource. In addition to concerns about the sustainability of fisheries resources, other issues including the potential presence of organic and inorganic contaminants in fish meal and the net effect of demand-and-supply economics in the global market require enhanced efforts to thoroughly evaluate reasonable alternatives such as various plant feedstuffs.

The US soybean industry has identified the potential demand for plant protein in aquafeeds as an opportunity to increase the use of US soybeans. Since 1995, the United Soybean Board (USB) has funded market-development activities, primarily in China. This programme has increased demand for soybean meal (SBM) for farm-raised fish from almost 0 to an estimated 5 million metric tonnes (mmt) in 2005. In 2002, USB created a Managed Aquaculture Programme, the Soy-in Aquaculture-Initiative (SIA), with the joint objectives of expanding its marketing initiative and conducting research on the factors in SBM that limit its use in salmonids. Nevertheless, there are still unidentified biologically active compounds that limit the amount of SBM and other plant feedstuffs in diets of carnivorous species, including most marine species of commercial importance (existing or poten- tial) as well as salmonids. For reasons that are not clear, carnivorous species have limited tolerance to SBM that ranges from none in juvenile chinook salmon (Oncorhynchus tshawytschaWalbaum) to possibly somewhat higher in diets for rainbow trout, O. mykiss Walbaum (Olli \& Krogdahl 1994), and Atlantic salmon, Salmo salar L. (Olli, Krogdahl, van dan Ingh \& Brattås 1994; Bæverfjord \& Krogdahl 1996; Krogdahl, Bakke-McKellep \& Baeverfjord 2003). The salmon aquaculture industry is clamoring for a stable source of protein in terms of cost and supply, and such a supply would benefit other established and emerging sectors of the aquaculture industry as well.

\section{Targeted nutritional and non-nutritional characteristics (including cost) of plant- derived feedstuffs for inclusion in aquafeeds}

Fish meal has been the protein source of choice in aquafeeds for many reasons, including its high protein content, excellent amino acid profile, high nutrient digestibility, general lack of antinutrients, relative low price (until recently) and its wide availability. Plant-derived feedstuffs all have some characteristics that place them at a disadvantage to fish meal in terms of their suitability for use in aquafeeds. However, demand for protein ingredients is expected to exceed the annual world supply of fish meal in the next decade, and this increased demand will change the economic and nutritional paradigms that up to now have resulted in high use levels of fish meal in aquafeeds. The plant feedstuffs considered in this document include oilseeds, legumes and cereal grains, which traditionally have been used as protein or energy concentrates as well as novel products developed through various processing technologies. Lipid composition of these feedstuffs is not specifically considered although it is recognized that incorporating lipid supplements in aquafeeds to achieve proper fatty acid profiles to meet the metabolic requirements of fish and maximize human health benefits are important aspects.

To be a viable alternative feedstuff to fish meal in aquafeeds, a candidate ingredient must possess certain characteristics, including wide availability, competitive price, plus ease of handling, shipping, storage and use in feed production. Furthermore, it must possess certain nutritional characteristics, such as low levels of fibre, starch, especially nonsoluble carbohydrates and antinutrients, plus have a 
relatively high protein content, favourable amino acid profile, high nutrient digestibility and reasonable palatability. Although some plant-derived ingredients, such as soy protein concentrate (SPC) or wheat gluten, possess most of these characteristics, they have been too expensive relative to the price of fish meal to be used in most aquafeeds. It is likely that a combination of plant-derived feed ingredients will be required to replace fish meal, and that supplements, such as amino acids, flavourings and possibly exogenous enzymes, will be needed to produce aquafeeds without fish meal that support growth rates necessary for the economic production of farmed fish. Table 1 summarizes the nutrients found in fish meal (expressed on an as-fed basis), and the range of nutrient concentrations that alternative ingredients should have to be viable alternatives to fish meal. Various grain and oilseed crops are grown in the United States, and their recent production is summarized in Table 2. The gross nutrient composition of these and other plant feedstuffs are presented in Table 3.

\section{Candidate plant products for increased use in aquafeeds}

\section{Soybean}

Soybean, Glycine max Linnaeus, is the leading oilseed crop produced globally and its projected production

Table 1 Proximate and nutrient content (as-fed basis) of fish meal, and targeted ranges in alternative ingredients derived from grains and oilseeds

\begin{tabular}{lll}
\hline & $\begin{array}{l}\text { Fish } \\
\text { meal } \\
\text { (menhaden) }\end{array}$ & $\begin{array}{l}\text { Target range } \\
\text { for alternative } \\
\text { ingredients }\end{array}$ \\
\hline Crude protein (\%) & $65-72$ & $48-80$ \\
Crude lipid (\%) & $5-8$ & $2-20$ \\
Fibre (\%) & $<2$ & $<6$ \\
Ash (\%) & $7-15$ & $4-8$ \\
NFE (\%) & $<1$ & $<20$ \\
Starch (\%) & $<1$ & $<20$ \\
Non-soluble CHO (\%) & None & $<8$ \\
Arginine (\%) & 3.75 & $>3.0$ \\
Lysine (\%) & 4.72 & $>3.5$ \\
Methionine (\%) & 1.75 & $>1.5$ \\
Threonine (\%) & 2.5 & $>2.2$ \\
$\omega-3$ fatty acids & $\sim 2 \%$ & $*$ \\
\hline
\end{tabular}

${ }^{*}$ The fatty acids provided by alternative protein feedstuffs vary considerably and lipid supplements will be the primary source of fatty acids.
Table 2 Grain and oilseed production in the United States

\begin{tabular}{lclr}
\hline $\begin{array}{l}\text { Grain or } \\
\text { oilseed }\end{array}$ & $\begin{array}{l}\text { Acres } \\
\text { planted }\end{array}$ & $\begin{array}{l}\text { Production } \\
(\times \mathbf{1 0 0 0} \text { bushels })\end{array}$ & \multicolumn{1}{c}{$\begin{array}{l}\text { Metric } \\
\text { tonnes }\end{array}$} \\
\hline $\begin{array}{l}\text { Barley } \\
\text { Canola } \dagger\end{array}$ & 3875000 & 352445 & 7689709 \\
Corn & 81759000 & 9761085 & 248463980 \\
Cottonseed & 14195400 & & 7711980 \\
Oat & 4246000 & 114878 & 1667450 \\
Peanut & & & \\
Peas/lupins $\dagger$ & 1657000 & 4821250 & 2186880 \\
Rice & 3384000 & 223235 & 10125770 \\
Soybeans & 72375000 & 2756794 & 75185291 \\
Sunflower & 2709000 & 4018355 & 1822700 \\
Wheat & 65871000 & 2550383 & 69555900 \\
\hline
\end{tabular}

*A bushel of barley, corn, soybeans and wheat weighs $48,56,60$ and 60 pounds respectively.

$\nmid$ Production of canola, peas and lupins in the United States is negligible.

Source: USDA Agricultural Statistics (2005), http://www.nass. usda.gov.

for 2004-2005 is expected to exceed $200 \mathrm{mmt}$. A large part of this production is used in the extraction of oil yielding a cake of high protein quality. This is processed to yield a wide array of soybean products, such as soy flour, SBM, SPC and soy protein isolate (SPI) that have been evaluated in fish. Full-fat SBM (heat-treated whole soybeans) also has been evaluated in fish. Soybean meal has been the predominant form of soybean used and is available either as dehulled ( $\sim 48 \%$ crude protein) or with hulls added ( $\sim 44 \%$ crude protein) (NRC 1993).

Soy products are regarded as economical and nutritious feedstuffs with high crude protein content and a reasonably balanced amino acid profile. However, certain nutritional characteristics and the presence of several antinutritional factors merit discussion. Concentrations of the 10 essential amino acids (EAA) and tyrosine are generally lower in SBM than in fish meal with the exception of cystine, which is present at higher concentrations in SBM. The EAA of concern are lysine, methionine and threonine that may be limiting in soy-based diets fed to aquatic animals. Concentrations of these EAA increase with processing of soy flakes to SPC and SPI and approach or exceed those found in fish meal. However, due to the processing costs involved, these products are not yet economical for large-scale use in aquafeeds. Crude fat and ash concentrations of solventextracted SBM and other soy products tend to be lower than those in fish meal, but carbohydrate concentrations tend to be higher. Lower ash and fat 
Table 3 Typical composition (as-fed basis) of fish meal and various plant feedstuffs

\begin{tabular}{|c|c|c|c|c|c|c|c|c|}
\hline Ingredient & $\begin{array}{l}\text { International } \\
\text { feed number }\end{array}$ & $\begin{array}{l}\text { Dry matter } \\
(\%)\end{array}$ & $\begin{array}{l}\text { Protein } \\
(\%)\end{array}$ & $\begin{array}{l}\text { Lipid } \\
(\%)\end{array}$ & $\begin{array}{l}\text { Ash } \\
(\%)\end{array}$ & $\begin{array}{l}\text { Lysine } \\
(\%)\end{array}$ & $\begin{array}{l}\text { Methionine } \\
(\%)\end{array}$ & $\begin{array}{l}\text { Cystine } \\
(\%)\end{array}$ \\
\hline Fish meal, herring* & $5-02-000$ & 92.0 & 72.0 & 8.4 & 10.4 & 5.57 & 2.08 & 0.74 \\
\hline Barley $\dagger$ & $4-00-552$ & 88.0 & 14.9 & 2.1 & 2.9 & 0.44 & 0.16 & 0.24 \\
\hline Canola* & $5-06-145$ & 93.0 & 38.0 & 3.8 & 6.8 & 2.27 & 0.70 & 0.47 \\
\hline Corn* & 4-02-935 & 88.0 & 8.5 & 3.6 & 1.3 & 0.25 & 0.17 & 0.22 \\
\hline Corn gluten meal* & $5-28-242$ & 91.0 & 60.4 & 1.8 & 2.1 & 1.11 & 1.63 & 1.20 \\
\hline Cottonseed meal* & $5-01-619$ & 92.0 & 41.7 & 1.8 & 6.4 & 1.89 & 0.50 & 0.45 \\
\hline Lupin Lupinus angustifolius $\ddagger$ (whole) & $5-27-717$ & 89.0 & 39.2 & 10.3 & 2.8 & 1.40 & 0.27 & 0.51 \\
\hline Field peas $\ddagger$ (whole) & $5-03-600$ & 89.0 & 25.6 & 1.3 & 3.4 & 1.50 & 0.21 & 0.31 \\
\hline Soybean meal, de-hulled* & $5-04-612$ & 90.0 & 48.5 & 0.9 & 5.8 & 3.08 & 0.68 & 0.75 \\
\hline Soy protein concentrate $\dagger$ & & 90.0 & 64.0 & 3.0 & 1.5 & 4.20 & 0.90 & 1.00 \\
\hline Wheat* & $4-05-268$ & 88.0 & 12.9 & 1.7 & 1.6 & 0.36 & 0.21 & 0.27 \\
\hline
\end{tabular}

* Data from NRC (1993).

†Data from NRC (1998).

țata from Allan et al. (2000).

concentrations in soy products can be overcome by appropriate supplementation with mineral premixes and lipids, but high concentrations of carbohydrates remain an area of concern. Carbohydrates in soybeans are largely present as oligosaccharides such as sucrose, raffinose and stachyose. Sucrose is generally available to aquatic animals, but raffinose and stachyose are not digestible due to a lack of $\alpha$-galactosidases that are necessary to metabolize these complex sugars. An added concern is the low availability of phosphorus and cationic minerals that are largely unavailable due to their being bound in or by phytic acid. The addition of the enzyme phytase to feeds has been shown to improve phosphorus and cationic mineral availability. There are differences in concentrations of vitamins between soy products and fish meal. Vitamin availability data in fish are scarce and feeds are generally fortified with vitamins assuming minimal availability from feedstuffs (NRC 1993).

\section{Barley}

Barley, Hordeum vulgare Linnaeus, is grown for multiple purposes including animal feeds, human food, malting for the production of alcoholic beverages or inclusion in extracts and syrups for adding flavour, sweetness and colour to a variety of prepared foods. Barley is a short-season, early-maturing crop grown on both irrigated and dry land production areas in the United States, primarily in the Northern Plains states and in the Pacific Northwest. The United States is the seventh-largest barley-producing country in the world, but is in the top five of exporting countries.
Feed barley is included in rations for many animal species, but has not been widely used in aquafeeds. Several factors have limited its use, but improvements in crop genetics and processing technology are improving the value of this ingredient for aquafeeds. New varieties are available including hullless (lower fibre) and low phytic acid varieties (Bregitzer 2005), both of which will help the aquaculture industry decrease nutrients and solids in effluent.

Waxy type varieties also are available in which the ratio of amylose to amylopectin has been altered. This may have a positive effect on energy availability, but also affects the ease of manufacturing. The waxy barley provides considerable binding capabilities for feeds produced by cooking extrusion. This is beneficial for the production of high protein and energy diets, because less carbohydrate is needed for pellet production (Barrows \& Hardy 2001).

While barley contains a good nutrient profile in its native state, the co-products resulting from the development of other products will allow such barley co-products to be included in higher amounts in aquafeeds. For example, although corn has been the traditional source of feed-stock for ethanol production, barley also shows considerable promise (Hicks, Taylor, Kohout, Kurantz, Thomas, O Brien, Johnston, Flores, Moreau \& Hoot 2004). In the Northern Plains and Pacific Northwest, barley may be the most economical source of fermentable carbohydrates for ethanol production. Methods are being developed to concentrate the protein from barley before fermentation for ethanol production (Flores, Eustace \& Hicks 2004). Owing to the amino acid pattern and protein content, this protein concentrate will be of high value to the aquaculture industry. 
Barley also contains high levels of $\beta$-glucans, which have been shown to have strong health benefits (Lupton, Robinson \& Morin 1994; Jenkins, Kendall, Vuksan, Vidgen, Parker, Faulkner, Mehling, Garsetti,Testolin, Cunnane, Ryan \& Corey 2002). Barley can be consumed directly to obtain these benefits, but $\beta$-glucans are being extracted, purified and manufactured into pills for the nutritional-supplement industry. This process, like ethanol production, will result in a protein concentrate as a co-product with high nutritional value.

\section{Canola}

Canola, Brassica rapa Linnaeus, is produced from cultivars of rapeseed that have been bred to contain low levels of erucic acid and glucosinolates, a group of antinutrients that interfere with normal thyroid function. Canola seed is an oilseed, and canola oil is the primary product of its cultivation. After oil is extracted and the solvent removed, the resulting meal (10\% moisture) contains about $3.5 \%$ residual oil, $35 \%$ crude protein, $6 \%$ ash and $12 \%$ crude fibre on an 'as-is' basis. It also contains about $4 \%$ phytic acid and $15 \mu \mathrm{mol}$ of glucosinolates $\mathrm{g}^{-1}$. The price of canola meal is linked to that of SBM, and reflects the protein content of the meal. Canola meal is not widely used in aquafeeds in the United States as it is not widely available, but is used in Canadian aquafeeds.

Canola meal can be further processed to produce a protein isolate, called canola protein concentrate (CPC). Canola protein concentrate has been widely tested as a protein source for salmonids and other carnivorous species of farmed fish. As the primary protein source in aquafeeds for salmon and trout, CPC supports growth rates similar to those of fish fed fish meal-based diets, as long as amino acid supplements are used to overcome limiting amino acid levels and providing feeding stimulants, such as betaine, are added to the diet to overcome reduced intake. Canola protein concentrate has a protein content similar to high-quality fish meal. At present, CPC is not widely available for use in aquafeeds, and market prices have not been established.

\section{Corn}

Production of corn, Zea may Linnaeus, is higher than any other grain or oilseed in the United States, but in contrast to other grains, only a small percentage of annual production is consumed directly by humans.
Corn oil is the primary food product of corn production and although most corn grown in the United States is fed to livestock as an energy source, an ever increasing amount is going to ethanol production. Corn starch is used to produce over 400 products, including ethanol, paper coatings and corn syrup, a widely used sweetener in foods and beverages.

In the wet-milling process, the corn kernel is separated into its main components, bran/fibre, germ, gluten and starch. The oil is separated from the germ and the remaining corn germ meal is used as an ingredient or added to corn gluten feed. The gluten protein is concentrated, filtered and dried to form corn gluten meal. The commonly traded corn gluten meal is guaranteed to contain a minimum of $60 \%$ protein on an 'as-is' basis. Refined and purified corn gluten protein can have a crude protein content of $70-73 \%$ crude protein, but there are limits in the commercial production process so these levels cannot always be met. A higher crude protein corn gluten meal would be a more suitable product for use in aquafeeds although the price would be higher than commercially traded corn gluten meal. Economic and marketing analysis is required to determine if the production of a highprotein corn gluten meal is warranted.

Corn gluten meal is currently widely used in aquafeeds for salmon and several marine species such as European sea bass, Dicentrarchus labrax Linnaeus and gilthead sea bream, Sparus aurata Linnaeus. Corn gluten meal protein is highly digestible, but deficient in the EAA lysine. This characteristic and its crude protein content result in upper inclusion limits of $20-25 \%$ of diet for corn gluten meal in aquafeeds for salmon and marine fish. Generally, use levels are in the $10-15 \%$ range.

Corn distillers dried grains with solubles (DDGS) is the ending co-product of ethanol production. Conventional DDGS contains $28-32 \%$ crude protein and is relatively high in fibre content, which limits its use in aquafeeds. Ethanol production is expected to increase substantially in the United States, and research is underway to explore the possibility of removing protein and fibre from starch before using the starch to produce ethanol. If this approach becomes widespread, corn protein concentrate may become more readily available for use in aquafeeds.

\section{Cottonseed}

Cottonseed, Gossypium hirsute Linnaeus, is the third leading legume seed by weight (after soybean and rapeseed) used worldwide. Owing to its high protein 
value for human consumption (Alford, Liepa \& Vanbeber 1996) and animals, as well as low market price in comparison with other legumes and fish meal, cottonseed meal (CSM) consequently has an immense potential for incorporation in high-protein aquafeeds. The results of numerous studies evaluating CSM in catfish, salmonid and tilapia diets indicate that between $10 \%$ and $30 \%$ of solvent extracted, $40 \%$ protein CSM can be used in aquaculture diets without growth depression. However, these studies most frequently used the strategy of replacing one plant protein source with the other; whereas, more challenging and profitable would be to replace fish meal, or other animal protein sources. Lee, Dabrowski, Blom, Bai and Stromberg (2002) used an approach to entirely replace fish meal with a mixture of animal by-product and both SBM and CSM in diets for juvenile rainbow trout with extremely positive results. However, the authors also pointed out that the source of CSM and related processing influences utilization of CSM in fish diets. Lee, Rinchard, Dabrowski, Babiak, Ottobre and Christensen (2006) summarized a series of studies in rainbow trout where CSM replaced fish meal entirely over the 3-year period without significantly impacting growth rate of female and male rainbow trout, although diets with CSM had significantly lower protein and phosphorus assimilation. In one study, channel catfish, Ictalurus punctatus Rafinesque, were raised at high densities in earthen ponds and fed to satiation a diet containing $51 \%$ CSM with supplemented lysine (0.65\%). Results indicated that growth rate, dressout percentage and chemical composition of the fillets did not differ significantly from fish fed diets containing SBM (42\%) (Robinson \& Li 1994). Fowler (1980) demonstrated that up to $34 \%$ of CSM can be used in the diet for two Pacific salmon species to replace SBM without growth depression.

\section{Peas/lupins}

Peas, Pisum sativum Linnaeus, and lupin, Lupinus sp. Linnaeus, are common plant ingredients either already being used or considered for use in aquafeed for marine and freshwater fish throughout the world (Allan \& Rowland 1994; Allan, Parkinson, Booth, Stone, Rowland, Frances \& Warner-Smith 2000; Glencross, Boujardand \& Kaushick 2003; Glencross, Curnow, Hawkins, Kissil \& Peterson 2003; Thiessen, Campbell \& Tyler 2003; Dias, Rueda-Jasso, Panserat, Conceicao, Gomes \& Dinis 2004; Glencross, Carter,
Duijster, Evans, Dods, McCafferty, Hawkins, Maasand \& Sipsas 2004; Glencross, Evans, Hawkins \& Jones 2004). Both products are produced in significant quantities throughout the world. The 2004 production levels of peas and lupin were 9.1 and $1.0 \mathrm{mmt}$ respectively (FAOSTAT 2005). US production of peas in 2004 was $0.9 \mathrm{mmt}$, while lupin production was insignificant for the same period.

The nutrient profile of peas and lupin indicate that that they have the potential to replace significant proportions of fish meal protein in aquafeeds. When compared with animal meals such as fish meals, meat and bone meals and poultry meals, the protein content of peas and lupin are moderate, lysine and methionine are limited, and both contain high levels of carbohydrate (Allan et al. 2000). Carbohydrates are the primary component of peas and lupin (Table 3). Starch is the predominant energy reserve carbohydrate in peas, and may comprise approximately 55\% of the total seed. In contrast, lupins contain insignificant levels of starch $(<3 \%)$, with non-starch polysaccharides (NSPs) such as $\beta$-(1,4)-galactan acting as the primary energy storage carbohydrate (Anonymous 1992; van Barneveld 1999). In general, fish do not have the capacity to metabolize NSPs of plant origin (Stickney \& Shumway 1974; Kuz'mina 1996).

Studies investigating the nutritional value of peas and lupin as fish meal protein replacements for aquafeeds have been favourable. Thiessen, Campbell and Tyler (2003) reported protein apparent digestibility coefficient (ADC) values in excess of $90 \%$ for a range of pea products for rainbow trout, and also demonstrated that dietary levels of $25 \%$ dehulled peas could be used to replace SBM. Allan et al. (2000) reported excellent protein ADC values from lupin (>95\%) by the freshwater silver perch, Bidyanus bidyanus Mitchell. However, Glencross, Curnow et al. (2003) reported protein ADC values of $>95 \%$ for a range of lupin varieties by the red sea bream, Pagrus auratus Forster. Glencross, Curnow et al. (2003) also reported acceptable growth of juvenile red sea bream when fed lupin at up to $60 \%$ of diet. In all of the above-mentioned studies, energy ADCs were low for pea and lupin products (range 51-78\%). This is indicative of the high level of indigestible carbohydrates present in these products.

\section{Wheat}

Wheat (Triticum aestivum Linnaeus. and T. diccoides, var. durum) is widely produced in the United States and unlike other cereals has at least six large 
subdivisions of cultivars that are based on end-use properties of the grain. Current production of bread wheat (T. aestivum) in the United States is approximately $60 \mathrm{mmt}$ (NASS http://usda.mannlib.cornell.edu/usda/). Although wheat is primarily milled for human consumption, 7-9\% of US production is used in animal feeds as grain and nearly all of mill feed (the $20-25 \%$ of kernel that is a by-product of flour production) is used in animal diets. The functional characteristic of wheat that differentiates it from other cereal grains is the presence of large seed storage protein that forms the cross-linking networks of gluten when hydrated flour is mixed. Gluten gives dough it elastic characteristics and the ability to retain gasses produced by leavening agents. Gluten is also an effective binder of aquafeeds because of its strength and limited water solubility. Traditional preparations of wheat for diets have utilized flaking (roll milling) of whole grains or pelleting of mill feed and grains. A rapidly increasing use of wheat in Europe and North America is cereal fractionation, the separation of vital wheat gluten from other seed components and further decomposition into starch, soluble fibre and oil. Although still a relatively small portion of total usage in North America $(<1 \%)$, usage of components is increasing driven by baking industries that are seeking greater control over the finished product either for quality control or nutritional marketing. The availability of wheat fractions could increase the flexibility of formulations for aquaculture, particularly for feed mills and aquaculture areas proximal to grain fractionation facilities.

The wheat kernel in publications of composition is often assumed to be $12 \%$ protein by weight at $12 \%$ moisture (FAO 1970; Bushuk \& Wrigley 1974). However, grain used in animal diets is often composed of less-costly soft wheat, which tend to be low in protein as a class $(<10 \%)$ or lower protein lots $(<11 \%)$ of hard endosperm wheat that failed to make milling grade. Like other cereals, whole grain wheat is primarily an energy source based on its high starch composition (typically $>70 \%$ ) rather than a source of protein. In addition to protein and starch, wheat kernels are approximately $2 \%$ crude fibre and $<2 \%$ ash (Martin, Leonard \& Stamp 1976). The greatest components of the ash fraction are potassium $(0.40 \%)$, phosphorus $(0.38 \%)$ and sulphur $(0.20 \%)$, with calcium $(0.04-0.05 \%)$ as a relatively minor mineral constituent (Martin et al. 1976; Guttieri, Bowen, Dorsch, Souza \& Raboy 2004). Phosphorus in wheat is primarily sequestered in the aluerone layer in phytin, phytic acid with chelated metal ions. Phy- tic acid mutants in wheat can significantly reduce phytic acid concentration and enhance inorganic phosphorus levels that are nutritionally more readily available in the diet (Guttieri et al. 2004). However, previous work in grain crops (Raboy \& Dickinson 1993) and more recent studies in wheat and barley suggest that reducing phosphorus fertilization may reduce overall phytic acid levels in cereals while increasing nutritionally available phosphorus.

Protein quality in wheat is similar to other cereals with glutamic acid accounting for 30\% of total protein weight (FAO 1970). Nutritionally important amino acids, lysine and methionine are relatively minor constituents of the total, $3 \%$ and $1.5 \%$ respectively (FAO 1970). The amino acid composition of mill feed is improved over whole grain because the proteins are primarily enzymatic and structural proteins derived from the bran and embryo rather than the storage proteins of the endosperm. Wheat embryo proteins contain as much as $8 \%$ lysine and $2 \%$ methionine (Pomeranz, Carvajal, Hoseney \& Ward 1970). Mill feed, however, has several drawbacks in aquafeeds. First, the energy quotient is reduced because most of the digestible carbohydrate is removed in the production of flour. Secondly, the glutenin and gliadin storage proteins that form gluten are also removed in the milling process with the remaining proteins of the bran generally of poorer value for use as a feed binder. The remaining mill feed is high in crude fibre ( 10\%, Martin et al. 1976) of limited digestibility for monogastric animals and has a more concentrated phytic acid composition that reaches nearly $0.5 \%$ of total weight (Guttieri et al. 2004).

\section{Bioactive compounds in and/or nutritional limitations of plant products}

\section{Soybean \\ Carbohydrate fractions}

Non-starch polysaccharides. Soybeans are characterized by a high content of NSPs and negligible starch. The high NSPs content represents a major challenge for the use of soybean products in fish diets. This fraction provides marginal energy for the fish due to limited microbial fermentation, and may negatively affect nutrient utilization and reduce feed efficiency. A review of soy products (Storebakken, Refstie \& Ruyter 2000) indicated raw soybeans contain in the range of $20 \%$ NSPs, approximately onethird of which are soluble and another fraction is 
highly viscous. Elevated faecal water content has been reported in salmonids when fed diets with SBM (Olli, Hjelmeland \& Krogdahl 1994; Refstie, Storebakken \& Roem 1998; Storebakken, Kvien, Shearer, Grisdale-Helland, Helland \& Berge 1998), which probably in part is related to the NSPs content of SBM. Furthermore, Refstie, Svihus, Shearer and Storebakken (1999) attributed a trend of reduced digestibility of fat and protein in both Atlantic salmon and broiler chickens to increased intestinal viscosity due to dietary soybean NSPs. Soybean NSPs increased the viscosity of the intestinal contents of chickens, which is an indicator of, and possibly a major reason for, the disturbed absorption of nutrients in birds fed diets rich in soluble NSPs such as mixed-linked $\beta$-glucans from barley (Almirall, Francesch, Perez-Vendrell, Brufau \& Esteve-Garcia 1995) and arabinoxylans in rye (Bedford \& Classen 1992) or wheat (Choct, Hughes, Wang, Bedford, Morgan \& Annison 1996). In some fish, however, soybean NSPs have been shown to increase intestinal and faecal water contents without affecting the intestinal viscosity. In spite of this, the antinutritional effects were the same including reduced digestibility of fat and nitrogen with soy products containing the most NSPs. Similar but more severe effects on nutrient absorption and faecal water content occur in rainbow trout when using NSPs such as guar gum and alginates as binders in aquafeeds (Davies 1985; Storebakken 1985; Storebakken \& Austreng 1987).

The antinutritional actions of soluble NSPs are still not fully understood. Increased viscosity of the intestinal contents may subsequently impair diffusion and convective transport of digestive enzymes and substrates within the gastrointestinal contents. However, antinutritional effects also probably are associated with binding or trapping of and subsequent increased faecal excretion of steroids, in particular bile acids, as seen with galactomannans in rats (Levrat, Moundras, Younes, Morand, Demigne \& Rémésy 1996; Favier, Bost, Guittard, Demigné \& Rémésy 1997; Moundras, Behr, Rémésy \& Demigné 1997). As NSPs do not appear to affect intestinal viscosity in fish, this latter effect may be responsible for the reduced nutrient absorption with NSPsrich diets. Non-starch polysaccharides also may have similar effects as do oligosaccharides on water balance in saltwater fish; these effects could be additive when feeding diets with oligosaccharide-containing soy meals. Increased drinking has been indicated by an increase in faecal output of sodium in Atlantic salmon fed diets with high amounts of oligosaccharide-free SPC, independent of dietary phytate concentration (Storebakken et al. 1998).

Oligosaccharides. Soybean meal contains oligosaccharide levels of up to $15 \%$ (Russett 2002). In contrast, oligosaccharide levels in SPC are $\sim 3 \%$ (Russett 2002). Stachyose and raffinose are the two most predominant oligosaccharides in SBM. Oligosaccharides commonly found in SBM have been reported to be indigestible to fish (Refstie et al. 1998). They also have been reported to increase the viscosity of the chime in the digestive tract and interfere with the uptake of nutrients, particularly fat and minerals, in salmonid species (Refstie et al. 1998; Refstie, Sahlstrom, Brathen, Baeverfjord \& Krogedal 2005). The oligosaccharide component of SBM also has been linked with reduced growth performance (Refstie et al. 1998) and the occurrence of SBMinduced enteritis in several salmonid fish species (van den Ingh, Krogdahl, Olli, Hendrix \& Koninkx 1991; van den Ingh, Olli \& Krogdahl 1996; Bureau, Harris \& Cho 1998). In Atlantic salmon, the enteritis develops rapidly during the first weeks of exposure even at SBM inclusion levels as low as $10 \%$ of diet and regresses to apparently normal histology 3 weeks after introduction of a diet without SBM (Bæverfjord \& Krogdahl 1996). Van den Ingh et al. (1996) fed Atlantic salmon a series of diets containing 26\% SBM that had been exposed to a range of heat treatments to denature trypsin inhibitor as well as a fish meal-based diet in which the alcohol-soluble components of SBM were added back, and two control fish meal diets containing no soy products. Control diets failed to induce any morphological changes in the intestinal tract whereas morphological changes were evident in all fish fed diets containing SBM and the diet containing the alcohol-soluble extract. The alcohol-soluble extract contained oligosaccharides saponins and possibly low levels of other antinutrients, known as well as unknown. Van den Ingh et al. (1996) suggested that the antinutritional factor was in the alcohol-soluble component of the SBM and concluded that either saponins or oligosaccharides were possible candidates. However, in a trial screening with isolated soybean antinutrients, oligosaccharides, trypsin inhibitors, saponins or lectin did not show any enteritis-inducing effect (Krogdahl 1996).

As soybean oligosaccharides are indigestible and are linked with reduced nutrient uptake and growth performance as well as with the occurrence of soybean-induced enteritis, ultimately it would be 
desirable to have a soybean product where the oligosaccharide component has been altered or removed completely. Fermentation, by either bacterial or fungal organisms (Refstie et al. 2005, R. Barrows, pers. comm.), may be used to reduce the negative effects of soybean oligosaccharides on nutrient digestibility and growth performance in fish. Oligosaccharides also may be removed during the production of SPC.

Seed proteins including antigenic compounds, protease inhibitors and lectins

Often, when SBM inclusion in aquafeed exceeds a certain level, impaired utilization occurs due to reduced feed intake, growth and development of intestinal enteritis (Bakke McKellep, Press, Baeverfjord, Krogdahl \& Landsverk 2000). These conditions may be related to protein toxicity by antimetabolic proteins such as lipoxygenase, lectins, urease and trypsin inhibitors as well as possibly by an immunological-based food intolerance that is essentially a food allergy. Trout and salmon fed diets containing high levels of SBM, for example, may exhibit skin lesions, gastrointestinal tract alterations and excess mucus excretion in the faeces. This mimics the foodallergy response to soybean in some humans, swine and mice where atopic skin response or hives and diarrhoea with massive mucus is a prompt response to allergic challenge, with continuing exposure leading to intestinal morphology changes in the form of enteritis, which may lead to autoimmune disease.

Recognition of a food intolerance that is immunologically rather than bioactivity based imposes a different set of problems and solutions to utilizing SBM in aquafeeds. Most bioactive proteins are easily inactivated by heat treatment that is part of feed production. However, immunological intolerance may only require the physical presence of the protein and not its enzymatic activity; therefore, heat and other processing treatments will not significantly alter allergenicity.

Antigenic proteins. Allergenic responses in mammals to seeds (Herman 2004) almost always involve sensitivity to multiple different proteins. Seed-protein intolerance is often not restricted to a single sensitizing crop species but rather it is more often manifested as a broader intolerance extending across species. The large majority of seed protein content results from the expression of gene families including the legumin and vicilin storage proteins, prolamine sto- rage proteins, lectins, trypsin inhibitors and oleosin, a protein associated with seed oil storage. The genes that encode these proteins from diverse species are very similar in sequence and the resulting protein products similar in three-dimensional structure and sequence. Because of the similarity of the proteins' structure among species, antibodies produced in response to protein exposure from one species are often cross-reactive with the homologous protein of another species.

Globular storage proteins in soybeans such as glycinin and $\beta$-conglycinin or their breakdown products may be involved in causing allergic reactions in animals. The severity of such reactions varies considerably in various aquatic species. The effects of these proteins are reduced following heat treatment and processing.

Protease inhibitors. Legume seeds, as many other plant seeds, are equipped with one or more protease inhibitors that will inhibit proteolytic enzymes in the gastrointestinal tract of pests that commonly attack the seeds in fields (Liener 2000). As digestive proteases have been highly conserved through evolution, the plant protease inhibitors such as trypsin inhibitors also inhibit proteases in the gastrointestinal tract of monogastric animals. Enzymes of fish seem to be particularly sensitive to the protease inhibitors (Krogdahl \& Holm 1983). Heat treatment will inactivate protease inhibitors to a major extent. However, the heat needed for total inactivation of the inhibitors may reduce protein quality through oxidation and fusion with other components of the soybean. A compromise must therefore be made between inactivation and deterioration of protein quality, which may leave some inhibitors active. It is likely that the remaining inhibitors in concert with the indigestible heat-damaged protein are significant factors for explaining the generally lower nutrient availability of standard SBM and increased requirements for sulphur-containing amino acids often recognized in animals fed SBM (Drackley 2000). Although without compromising growth and protein digestibility, low levels of protease inhibitors in salmonid diets have been observed to trigger increased secretion of pancreatic proteases indicating increased use of metabolic resources, whereas at higher levels both protein digestibility and growth is compromised (Olli, Krogdahl et al. 1994). Investigation of processes taking place within the soybean proteins in general and protease inhibitors in particular during heat treatment and mechanisms of 
interference between digestive processes and products of heat treatment may lead to improved processing techniques for soybeans.

Lectins. One of several antinutritional factors found in soybeans and other plant feedstuffs are the bioactive group of glycoproteins known as lectins (NRC 1993; Francis, Makkar \& Becker 2001). Owing to their ability to agglutinate red blood cells they are also referred to as agglutinins or in the case of soybeans, soybean agglutinins (SBA). Concentrations of SBA in SBM are reported to be in the range of $10-200 \mu \mathrm{g} \mathrm{g}^{-1}$.

Lectins possess the ability to bind reversibly and specifically to carbohydrates and glycoconjugates, which is responsible for their numerous physiological effects. For example, lectins bind avidly with intestinal glycoproteins on the epithelial surface and interfere with nutrient absorption. Lectins easily avoid digestion and then pass into the intestine where they may bind with the epithelium. Some lectins may cause disruption of membrane integrity and the initiation of a cascade of immune and autoimmune events that ultimately lead to cell death. Lectins gain entry into circulation and may bind to organs. They may also increase permeability of membranes to other proteins increasing incidence of allergic reactions. In addition to the disruption of intestinal membrane integrity, lectins such as SBA have been observed in some cases to cause hypertrophy, hyperplasia, decreased nutrient uptake, decreased intestinal enzyme activity, increase gut length and mass as well as increase pancreatic secretions. Lectins also may have an effect on systemic insulin levels and may mimic its effects. In rats, for example, increasing doses of kidney bean lectins resulted in depressed plasma levels of insulin.

The effects of SBA on fish have not been as extensively studied as with terrestrial animals. However, early studies demonstrated alteration in intestinal structure and changes in immune function in fish fed high levels (60-70\%) of SBM in their diets. These diets also brought about decreased intestinal enzyme activity and decreased plasma insulin levels. However, these studies did not indicate the specific cause of the observed responses. In another study, rainbow trout and Atlantic salmon were fed diets containing SBM $(60 \%)$ and an SBM-free diet containing SBA at a concentration that would be encountered in an SBM-based diet at the $60 \%$ inclusion level. Significant damage to intestinal membranes was observed for both dietary treatments in both species of fish, indicating the involvement of SBA in the observed response.

In more recent studies, rainbow trout and Atlantic salmon were fed purified diets containing a range of SBA concentrations that would be found in SBM at $35 \%$ and $40 \%$ inclusion rates respectively. There was no evidence of damage to the intestinal epithelium in either species. Serum insulin levels in both fasted and fed fish were not affected by dietary lectin levels in rainbow trout, but a decline in serum insulin levels with increasing dietary lectin levels was observed in Atlantic salmon. Results from various studies suggest that damage to intestinal structure may be occurring at SBM inclusion levels that are $>40 \%$ of diet.

Lectins, as discussed earlier, are resistant to proteolytic enzymes, but are either inactivated or destroyed by heat treatment. They are not affected by heating to $60{ }^{\circ} \mathrm{C}$ but are destroyed when heated to $100{ }^{\circ} \mathrm{C}$ for $5 \mathrm{~min}$. Lectins in a variety of legumes other than soybeans are not destroyed to any appreciable degree by extrusion. This is of great relevance as a majority of aquafeeds are manufactured using the process of extrusion. Another avenue that is open is the utilization of lectin-free SBM in aquafeeds. However, lectin-free lines of soybeans have not yet been evaluated in fish and present a future research opportunity.

\section{Oestrogenic compounds}

Oestrogenic activity of soybean in fish was suspected based on vitellogenin appearance in male sturgeon fed commercial (animal/plant-based) diets; however, Pelissero, LeMenn and Kaushick (1991) can be credited for the first direct evidence. Pelissero, Bennetau, Babin, LeMenn and Dunogues (1991) extended those findings by directly examining oestrogenic activity (vitellogenin secretion in juvenile sturgeon) of isoflavones and cumestans by intraperitoneal injections of genistein, daidzein, equol and coumestrol and comparing with oestradiol. Oestradiol $\left(0.0001 \mathrm{mg} \mathrm{g}^{-1}\right.$ body weight), coumestrol $\left(0.05 \mathrm{mg} \mathrm{g}^{-1}\right)$ and genistein $\left(0.2 \mathrm{mg} \mathrm{g}^{-1}\right)$ injections resulted in similar vitellogenin increase, approximately $10^{3}$ compared with the control (vehicle).

When genistein aglycone was added into rainbow trout diets at 500 or $1000 \mathrm{mg} \mathrm{kg}^{-1}$ diet, there were no differences in blood plasma oestradiol concentrations of females throughout a 12-month sampling period whereas males showed many differences in 
steroid profiles (decrease in 11-ketotestosterone and testosterone) before and at the time of spawning (Bennetau-Pelissero, Breton, Bennetau, Corraze, LeMenn, Davail-Cuisset, Helou \& Kaushik 2001). Isoflavonoids also may affect steroidogenesis regulation and the amounts of circulating hormones by influencing sex steroid-binding proteins in plasma. However, affinity of genistein in competition with oestradiol is four orders of magnitude lower in Arctic charr (Tollefsen, Ovrevik \& Stenersen 2004). Human and rainbow trout plasma showed very weak binding affinities for daidzein and genistein, where concentrations higher than $10^{3}$ of oestradiol were needed to displace natural steroids (Milligan, Khan \& Nash 1998).

Oestradiol glucuronides were 10 times less potent than oestradiol when evaluated in sturgeon hepatocyte cultures producing vitellogenin (Latonnelle, LeMenn, Kaushik \& Bennetau-Pelissero 2002). However, when evaluated as relative affinity to oestrogen receptors, i.e. displacing $50 \%$ of radiolabelled oestradiol, oestradiol glucuronide was $10^{3}$ less efficacious in case of rainbow trout hepatic nuclear extract, and $1.5 \times 10^{3}$ less efficacious in case of sturgeon preparations (Latonnelle, Fostier, LeMenn \& BennetauPelissero 2002).

Bennetau-Pelissero, Latonnell, Lamonthe, Shinkaruk-Poix and Kaushik (2004) analysed total, glucuronidase aryl-sulphatase hydrolysed, genistein and daidzein concentrations in SBM and, based on an ELISA procedure, estimated a total of $2.6 \pm$ $0.27 \mathrm{mg} \mathrm{g}^{-1}$. This is very close to the concentration of isoflavonoids in SPI, $2.98 \pm 0.1 \mathrm{mg} \mathrm{g}^{-1}$ (Fang, Yu \& Badger 2004). The latter authors also estimated that more than $95 \%$ of genistein and daidzein are present as glycosides. The evidence in mammals suggests that in vivo exposure to isoflavonoids, or their potential effects on target tissues, requires glycoside hydrolysis in the gut, and deglucuronidation by microbial flora, and reabsorption before enterohepatic recycling to presume significant physiological role of these substances. Only fragmentary information is available concerning these processes in fish in order to understand the potential role in vivo. D'Souza, Skonberg, Camire, Guthrie, Malison and Lima (2005) reported that gensitein aglycone supplement in rainbow trout diets resulted in genistein accumulation in fish muscle although neither dose-response nor duration of feeding were evident to have an effect. However, metabolism and tissue deposition of dietary genistein aglycone as used in that study may differ from that of genistein glycosides, which are present in soybean products. Thus, further research is needed to directly compare dietary sources of genistein glycosides and aglycones with respect to hydrolysis, deposition and hepatic metabolism in fish.

Two studies on the effect of genistein on reproductive performance of striped bass (Pollack, Ottinger, Sullivan \& Woods III 2003) and European eel (Tzchori, Degani, Elisha, Eliyahu, Hurvitz, Vaya \& Moav 2004) are somewhat controversial. First, no negative effect of genistein aglycone at a dose as high as $8000 \mathrm{mg} \mathrm{kg}^{-1}$ diet was observed in striped bass after 6 weeks of feeding. Tzchori et al. (2004) used only 2 or $20 \mathrm{mg}_{\text {gensitein }} \mathrm{kg}^{-1}$ diet with juvenile eel of initial weight of $0.5 \mathrm{~g}$ expecting an oestrogenic effect (feminization) on sex differentiation. The authors claimed that the lower dose significantly increased the proportion of females ( $55 \%$ ) in comparison with controls (5\%).

\section{Phytic acid}

Approximately two-thirds of the total phosphorus in oilseed meals or grains and their by-product meals is present as phytic acid (phytate), the main storage form of phosphorus in seeds. The bioavailability of phytate phosphorus to fish and to virtually all monogastric animals is very low, with reports of phosphorus availability in SBM ranging from virtually nil (Riche \& Brown 1996) to $22 \%$ available (Sugiura, Dong, Rathbone \& Hardy 1998). Furthermore, phytic acid lowers the availability of certain divalent cations, notably zinc, to carnivorous species of fish (trout and salmon) and to omnivorous species (catfish), and also has been reported in some studies to reduce the apparent digestibility of protein. Heat treatment associated with extrusion pelleting does not improve the availability of phytate phosphorus in oilseed meals or grains or reduce antagonistic interactions with other essential nutrients. The only effective strategies to reduce the effects of phytic acid in SBM or other seed-derived products is to remove phytic acid by processing, hydrolyse it using the enzyme phytase or to utilize single-gene mutant varieties of grains and oilseeds in which a smaller percentage of total phosphorus in the seed is stored as phytate phosphorus. Low-phytate cultivars of corn, barley, wheat and soybeans have been developed but are not widely available as livestock feed ingredients. Microbial phytase is more effective at increasing phosphorus bioavailability in soybean and canola meals, and in wheat middlings, than in whole grains, such as wheat or barley (Cheng \& 
Hardy 2002). However, there are issues related to the heat sensitivity of phytase and its temperature of activity that must be resolved before phytase is regularly used in aquafeeds.

Soybean meal contains approximately $4 \%$ phytate. Phytate is concentrated in the process used to produce SPC (and other protein concentrates), because the phytate fraction stays with the protein fraction. Thus, SPC contains approximately $7-10 \%$ phytate, a $100 \%$ increase over SBM.

\section{Amino acid limitations}

Soybean protein is well known to be limiting in total sulphur amino acids (TSAA; methionine plus cysteine) when utilized in animal feeds. Soybean meal and SPC each contain TSAA at approximately $2.95 \%$ of protein. These levels have been demonstrated to be deficient in a wide variety of fish species.

Supplemental methionine can overcome part of the growth reduction observed when a large percentage of the total dietary protein is from soy origin. For example, Cai and Burtle (1996) demonstrated that an SBM-corn diet was deficient in methionine for channel catfish and supplementation of DL-methionine could improve growth rates and feed efficiency. Mambrini, Roem, Cravedi, Lalles and Kaushik (1999) also demonstrated a positive effect of DL-methionine supplementation when SPC was the primary protein source for rainbow trout. Although fish in neither of these experiments could attain growth rates equivalent to control fish receiving some fishmeal protein, DL-methionine supplementation did have a positive effect. Keembiyehetty and Gatlin III (1997) demonstrated that hybrid striped bass, Morone chrysops $\times$ M. saxatilis, could effectively utilize $55 \%$ SBM in the diet along with fishmeal and supplemental L- or DL-methionine to meet the TSAA requirement.

Supplementation of multiple amino acids to diets containing over $42 \%$ extruded SBM also has been demonstrated to alleviate growth retardation in rainbow trout (Yamamoto, Shima, Furuita \& Suzuki 2002), while Takagi, Shimeno, Hosokawa and Ukawa (2001) found that growth retardation in red seabream could be partially overcome when a high level of SPC (52\%) was included in the diet. These authors found that methionine appeared to be the first limiting amino acid for growth. Additional supplementation with lysine also improved growth, indicating it may be limiting as well. Floreto, Baker and Brown (2000), working with American lobster, Homarus americana Edwards, also determined that multiple amino acid supplements (methionine, arginine and tryptophan) to diets containing high levels of SBM improved growth and feed efficiency. Furuya, Pezzato, Barros, Pezzato, Furuya and Miranda (2004) observed similar responses with Nile tilapia when feeding more than $60 \%$ SBM. These authors supplemented a fish meal-free diet with methionine, lysine, threonine and dicalcium phosphate to attain growth rates and feed efficiency equal to fish consuming the fish meal-based control diet.

As noted across multiple species, cysteine can meet $40-60 \%$ of the TSAA requirement (Wilson 2002). Other sulphur-containing compounds that are metabolic derivatives of methionine and cysteine also may be limiting in aquafeeds when soy proteins are the primary protein source. Soybeans and other plant products do not contain taurine, which has been demonstrated to be conditionally indispensable for some fish species (Takeuchi 2001). Current research also has indicated that taurine may be limiting in all-plant protein diets, even for rainbow trout, which have some capacity to synthesize taurine from cysteine.

\section{Saponins}

In general, saponins have high toxicity to fish when applied externally (Roy, Munshi \& Dutta 1990) and preparations of saponin extracts from tea seed cake have been used to eradicate predacious fish in ponds (Chen \& Chen 1997). The majority of work on saponins has concentrated on Quillaja saponin (derived from the Quillaja saponaria Molina tree) because of its use in vaccine adjuvants (Oda, Matsuda, Murakami, Katayama, Ohgitani \& Yoshikawa 2003). Quillaja saponins, when administered before or with human gamma globulin (HGG), was able to increase absorption and appearance of HGG in the blood plasma of Nile tilapia (Jenkins, Harris \& Pulsford 1991). Quillaja saponins were recognized for their toxicity; however, supplementation of $0.6 \%$ cholesterol into a diet for chicks with $0.6 \%$ Quillaja saponins restored feed intake and growth of animals.

Bureau et al. (1998) concluded that 1500 and $3000 \mathrm{mg}$ of Quillaja saponins $\mathrm{kg}^{-1}$ diet added to salmonid feed already containing $32 \%$ of SPC caused significant intestinal damage and higher saponin concentrations depressed growth of chinook salmon and rainbow trout. These results require site-by-site comparison of purified soyasaponins and Quillaja saponins, to provide conclusive evidence with diets 
where no SPC is included, as it may be argued that SPC saponins had an additive negative impact on diet acceptance and utilization by salmonids.

Twibell and Wilson (2004) followed this finding with studies on channel catfish and were able to decrease the growth-depressing effect of SBM (55\% of the diet) when cholesterol supplement was added to the formulation. However, there was no effect of $2600 \mathrm{mg}$ of purified soyasaponins (97\% of soyasaponin B) on the feed intake of channel catfish. Francis, Makkar and Becker (2005) examined the role of dietary Quillaja saponin addition on performance, growth and fecundity of tilapia and common carp. The comparison of all dietary treatments was based on five individual fish per diet housed in metabolic chambers. It was apparent that control fishdepressed growth was directly associated with frequent mouth-brooding episodes during experiment, whereas in other treatments with less females, fish did not spawn any eggs. Therefore it can be concluded that growth data were not representative for group-feeding tilapia and confounded by an uneven sex ratio in treatments and reproduction of females. Therefore, at this time it can be concluded that there is no substantial, scientifically sound evidence to suggest any positive role of Quillaja saponins in fish nutrition.

\section{Barley}

The inclusion of barley in aquafeeds has been limited by several factors. Low protein, high fibre, $\beta$-glucan and phytate contents are important considerations for barley. These factors can be accommodated by specific formulations or through use of improved cultivars or products.

\section{Nutrient composition}

The protein content of barley ranges from $9 \%$ to $15 \%$ depending on variety, and also can vary due to environmental conditions. The higher protein varieties have increased value in aquafeeds, especially for carnivorous fish, as protein needs of these species are often in excess of $40 \%$ of diet (NRC 1993). Lysine is the first limiting amino acid in barley protein at approximately $3.6 \%$ of protein. For rainbow trout, this level will yield a deficit of approximately $0.35 \%$ lysine in the diet, which can be overcome by blending protein sources with high lysine contents or adding supplemental lysine. Arginine also will be marginally defi- cient in barley protein. The TSAA content of barley appears adequate for fish but the skewed ratio of methionine to cysteine in favour of cysteine may require some supplementation of methionine to the diets of fish utilizing high levels of barley protein (when available). The fibre content of barley $(6 \%)$ is twice that of wheat (NRC 1994). Fibre is indigestible to coldwater fish and only increases faecal output. De-hulling barely or the use of hulless varieties will reduce the fibre content making it more likely to be used in aquafeeds.

The value of barley to rainbow trout is increased when the feed is manufactured by cooking extrusion (Cheng \& Hardy 2003a). Dry matter digestibility increased from $44 \%$ to $67 \%$ when barley was extruded and energy digestibility increased to $70 \%$. Barley protein is well digested, and carbohydrate and energy only moderately digested by hybrid tilapia with protein, carbohydrate and energy digestibility coefficients of $87 \%, 60 \%$ and $63 \%$ respectively (Sklan, Prag \& Lupatsch 2004). Several approaches may improve digestibility of nutrients from barley. Linberg, Arvidsson and Wang (2003) noted small improvements in organic matter and starch digestibility for piglets from barley cultivars selected for varied amylose to amylopectin ratios. Kaiser, Bowman, Surber, Blake and Borowski (2004) also noted cultivar differences in digestibility of dry matter, starch and aciddetergent fibre utilizing rats as an experimental model. Differences in dry matter and energy digestibility coefficients may be due in part to the inability of monogastric animals to digest glucans and the effects glucans have on intestinal content viscosity (Bergh, Razdan \& Aman 1999). These authors determined that $\beta$-glucanase supplementation of poultry feeds can improve illeal digestibility of starch and dry matter from barley.

\section{Phytic acid}

Phytate phosphorus is another undesirable component of barley, as its ultimate fate is to be excreted and thus released in effluent. Barley may contain as much as $82 \%$ of its phosphorus as phytate phosphorus but varieties of low-phytate barley are available that will increase available P in barley (Sugiura, Raboy, Young, Dong \& Hardy 1999; Overturf, Raboy, Cheng \& Hardy 2003). The inclusion of microbial phytase also has been demonstrated to release phytate phosphorus in barley for absorption by rainbow trout (Cheng \& Hardy 2002). Phytate in barley is not desirable, but should not limit its use in aquafeeds. 


\section{$\beta$-glucans}

$\beta$-glucans occur in the bran of grasses such as barley, oats, rye and wheat, at concentrations of about $7 \%$, $5 \%, 2 \%$ and $<1 \%$ respectively. As with protein content, growing conditions and variety affect $\beta$-glucan composition (content and linkage types) of barley, and ranges from $4 \%$ to $11 \%$. The metabolic effects of glucans is not clear in fish but have been demonstrated to be immunomodulatory in some species (Sealey \& Gatlin III 1999). The duration of feeding $\beta$ glucan will determine its effect. Prolonged feeding may be detrimental and short-duration feeding may be beneficial. Although a body of evidence on the metabolic effects of $\beta$-glucan on fish is building, the levels and feeding protocols for use of barley are still being evaluated. In other livestock species, glucans have been detrimental to growth and feed efficiency.

\section{Canola}

\section{Glucosinolates}

As mentioned above, glucosinolates are compounds found in rapeseed/canola meal. Their hydrolysis products are antithyroid substances. Goitrin is the most potent of the hydrolysis products and acts by inhibiting the organic binding of iodine, whereas another hydrolysis product, thiocyanate, lowers iodine uptake by the thyroid. Thus, glucosinolates are not themselves harmful substances, as are their hydrolysis products. Supplementing additional iodine to the diet does not prevent thyroid insufficiency in fish fed diets containing rapeseed meal. Canola meal is produced from cultivars of rapeseed that have been bred to contain low levels of glucosinolates relative to levels found in rapeseed meal. Rapeseed meals contain from $3 \%$ to $8 \%$ glucosinolates, whereas canola contains $<0.2 \%$, a level below that causing physiological effects in fish.

\section{Erucic acid}

Erucic acid (C22:1, $n-9)$ is a normal constituent of rapeseed oil, and levels in oil from standard varieties of rapeseed range from $20 \%$ to $55 \%$ of the oil. Erucic acid is valuable for production of industrial lubricants from rapeseed oil, but deleterious in oils used for livestock and fish diets. Erucic acid is cardiotoxic, causing cardiac lesions in rats, even at low levels of $1-$ $2 \%$ of the lipid fraction. Varieties of rapeseed have been developed that contain reduced levels of erucic acid, and solvent extraction of rapeseed/canola following mechanical pressing of the seeds reduces the residual amount of erucic acid in canola meal to levels below that required to have pathological effects in fish.

\section{Phytic acid}

As mentioned above, phytic acid is the storage form of phosphorus in all seeds, including grains and oilseeds from which products used in livestock and fish feeds are produced. Levels in canola meal average $4.0 \%$, similar to that found in SBM. Total phosphorus in canola meal is $11 \mathrm{~g} \mathrm{~kg}^{-1}$, and phytate phosphorus accounts for about $8.3 \mathrm{~g} \mathrm{~kg}^{-1}$, or about $75 \%$ of the total phosphorus in canola meal. Treatment with phytase increases total phosphorus digestibility of canola meal to rainbow trout from $12 \%$ to $42 \%$ (Cheng \& Hardy 2002).

\section{Corn}

Pigments

Corn products contain xanthophylls, a group of yellow carotenoid pigments, and pigment levels are concentrated in corn gluten meal compared with the xanthophyll content of ground corn. Rainbow trout fed diets containing corn gluten meal deposit xanthophyll pigments in the muscle tissue, resulting in a yellow colour in fillets. For trout receiving diets lacking supplemental astaxanthin or canthaxanthin, corn gluten meal cannot be used, but in trout fed diets supplemented with these carotenoid pigments to produce red fillets, the presence of corn gluten meal in the diet does not affect fillet colour.

\section{Lysine limitation}

Corn is deficient in lysine compared with other grains and oilseeds, and in fish diets lacking protein ingredients produced from fish or animal/poultry byproducts, lysine is nearly always the first limiting amino acid. Thus, fish diets cannot be formulated to be amino acid sufficient when corn gluten meal is a major constituent unless supplemental lysine is provided. Corn gluten meal contains $1.02 \%$ lysine, compared with $4.7 \%$ in menhaden meal. Soybeam meal contains $3.02 \%$ lysine and SPC contains $4.23 \%$ lysine. Thus, combining corn gluten meal with SBM or SPC may result in a blend containing lysine at nearly acceptable levels. 


\section{Cottonseed meal}

Gossypol

Cottonseed meal typically contains about 400$800 \mathrm{mg}$ of free gossypol kg ${ }^{-1}$, a compound recognized for its toxicity to animals, especially in regard to reproduction. Herman (1970) indicated that in rainbow trout growth depression did not occur at gossypol concentrations lower than $290 \mathrm{mg} \mathrm{kg}^{-1}$ diet whereas histopathological changes in the liver and kidney were noticed at $95 \mathrm{mg} \mathrm{kg}^{-1}$. Gossypol accumulated in the liver when trout were fed $1000 \mathrm{mg}$ of gossypol acetate $\mathrm{kg}^{-1}$ diet for several months. Lee et al. (2002) examined concentrations of gossypol isomers in liver, muscle, kidney, intestine and gonads following 9 months of feeding rainbow trout low and high levels of CSM-containing diets. This study indicated lower retention of the $(-)$ rather than $(+)$ gossypol isomer. Administration of gossypol by peritoneal injections established effects of water temperature, injection dose and isomer composition in tissues of rainbow trout that would allow estimation of post-prandial behaviour of gossypol and its major metabolite, gossypolone (K. H. Park and K. Dabrowski, pers. comm.). Channel catfish fed diets containing CSM at $29 \%$ of diet with an equivalent amount of gossypol acetate $(0.156 \%)$ had $1.8-2.2 \mathrm{mg}$ of gossypol kg-1 of muscle tissue (Dorsa, Robinette, Robinson \& Poe 1982). Robinson and Tiersch (1995) found that mature catfish fed diets containing CSM at either $37.5 \%$ or $52 \%$ (300 or $400 \mathrm{mg}$ of free gossypol $\mathrm{kg}^{-1}$ diet) gained less weight than fish fed either a control diet (no CSM) or a diet with 25\% CSM. Gossypol concentrations in liver were proportional to dietary CSM levels.

Further studies should address the means of gossypol detoxification at the gastrointestinal level for preventing pathological changes in haematology, for instance in tilapia Oreochromis sp. (Rinchard, Mbahinzireki, Dabrowski, Lee, Garcia-Abiado \& Ottobre 2002; Garcia-Abiado, Mbahinzireki, Rinchard, Lee \& Dabrowski 2005), preventing inhibition of pepsin and trypsin, as well as accelerating removal of gossypol via bile and post-absorptive transport. Impaired absorption of gossypol may allow complete utilization of CSM protein, and realization of growth-promoting effects, for instance, via flavonoid contributions (antioxidant action) or steroidogenesis, as stimulation of testosterone concentrations have been observed in rainbow trout (Dabrowski, Rinchard, Lee, Blom, Ciereszko \& Ottobre 2000) and tilapia (Rinchard et al. 2002).

\section{Quercitin}

Quercetin is rapidly metabolized to isorhamnetin, which is a weaker antioxidant in animals (Manach, Texier, Morand, Crespy, Regerat, Demigne \& Remesy 1999) but may have oestrogenic effects. Considering the rapid conversion of quercetin in mammalian cells (Manach, Morand, Crespy, Demigne,Texier, Regerat \& Remesy 1998), the prolonged presence in its parent form in fish diets may be an advantageous asset vis-a-vis its pharmacological effects.

Both quercetin and isorhamnetin exist almost exclusively as glucuronides/sulphates (Piskula \& Terao 1998; Erlund, Kosonen, Alfthan, Maenpaa, Perttunen, Kenraali, Parantainen \& Aro 2000; Wittig, Herderich, Graefe \& Veit 2001; Hou, Chao, Ho,Wen \& Hsiu 2003). In preliminary studies, low levels of quercetin and isorhamnetin were occasionally detected in liver and body tissues of tilapia reared for 15 weeks but not supplemented with quercetin. The source of quercetin in this case might have been algae growing on tank walls, but this was not ascertained, thus implying that Nile tilapia has a unique ability to absorb and accumulate quercetin. It is not yet known whether quercetin absorption is much more efficient in tilapia compared with other fish, considering the relatively high levels of quercetin in CSM (when supplemented at $54 \%$ ) and the failure to detect quercetin in rainbow trout blood plasma (K. J. Lee \& K. Dabrowski, pers. comm.).

\section{Peas/lupins}

Alkaloids

The predominant antinutrients for fish in lupins are the quinolizidine alkaloids (Duke 1981). There are over 300 species of the genus Lupinus (L.), of which many contain high levels of alkaloids ('bitter' varieties). These alkaloids, a class of bitter-tasting compounds, make the seed unpalatable and sometimes toxic to animals.

There are several different alkaloids present in lupins, and for cattle, Duke (1981) reported 'lupin poisoning' due to quinolizidine alkaloids or their $\mathrm{N}$ oxides, and ranked the toxins in order of increasing importance: D-lupanine, sparteine, lupanine, spathulatine and hydroxylupanine. As the alkaloids are not heat labile, they have traditionally been removed by soaking the seed in water; however, plant breeders have selected strains of alkaloid-free or 'sweet' lupins, which could be directly consumed by livestock (Duke 
1981). Commercially available strains of lupins that are commonly used for livestock are 'sweet' types such as white lupin (L. albus Linnaeus), yellow lupin (L. luteus Linnaeus) and blue or narrow-leafed lupin (L. angustifolius Eastwood) (Waldroup \& Smith 1989; Nelson \& Delane 1990). These strains are usually very low in alkaloid $\left(20 \mathrm{mg} \mathrm{kg}^{-1}\right)$ when compared with 'bitter' seeds that have a much greater alkaloid level (15000-22 $000 \mathrm{mg} \mathrm{kg}^{-1}$ ) (Luckett 2004). Low alkaloid strains of lupins do not appear to present palatability problems to fish. Glencross, Carter et al. (2004) fed diets containing up to a $50 \%$ inclusion level of yellow lupin kernel meal for 42 days to rainbow trout and found no evidence of reduced feed intake. However, growth performance was limited when lupin meal was included in the diets beyond 30\% (Glencross, Carter et al. 2004).

Oligosaccharides

Moderate levels of oligosaccharides are present in lupins and field peas (Duke 1981; Hickling 2003). The oligosaccharide component of lupins and field peas are mainly composed of $\alpha$-galactosides (Guillon \& Champ 2002), which are indigestible by most species of fish (Stickney \& Shumway 1974; Kuz'mina 1996). The oligosaccharide levels of lupins and field peas may vary between strains but they are approximately $8 \%$ (predominantly stachyose 3\%, sucrose $2 \%$, verbascose $2 \%$ and raffinose $0.8 \%$ ) and $\sim 5.0 \%$ (predominantly sucrose $2 \%$ and verbascose $1.5 \%$ and raffinose $0.5 \%$ ), respectively, of the total seed on a dry basis (Guillon \& Champ 2002; Hickling 2003).

The oligosaccharide levels of lupins and field peas are low compared with levels of $15 \%$ found in SBM (Russett 2002), and may present less of a problem. The oligosaccharide component of SBM have been linked with reduced digestibility, growth performance (Refstie et al. 1998) and the occurrence of SBM-induced enteritis in several salmonid fish species (van den Ingh et al. 1996; Bureau et al. 1998). While there was evidence of reduced digestibility due to the oligosaccharide component of lupin (L. angustifoilius) meal for rainbow trout (Glencross, Boujardand et al. 2003), there was no evidence of a condition similar to SBM-induced enteritis in rainbow trout fed diets containing 50\% inclusion level of yellow lupin kernel meal for 42 days (Glencross, Evans et al. 2004).

\section{Lysine limitation}

For lupins and field peas, both lysine and methionine are limiting amino acids (Table 3). Therefore, diets based on lupins or pea seeds will require added supplemental lysine and methionine. Ultimately, for the inclusion of lupins and field peas into fish diets it would be desirable to develop strains higher in lysine and methionine, remove the oligosaccharide component of both legumes and ensure selection of low alkaloid strains of lupins.

\section{Wheat \\ Lysine limitation}

Lysine is the most limiting indispensable amino acid in wheat for various aquatic species. Wheat breeding has long emphasized improvements in grain and flour quality with steady improvements in the gluten strength of cultivars grown by farmers (Cox, Shogren, Sears, Martin \& Bolte 1989; Souza,Tyler, Kephart \& Kruk 1993). Because of the importance of dough rheology in the end-use of bread wheats, selection has emphasized functional differences in seed storage proteins rather than selection to enhance nutritional composition, such as elevating the percentage of lysine and methionine. Wheat, like other related cereals, has only limited variation for seed amino acid composition. Transgenic modification of seed storage proteins is possible but would be likely to encounter stiff opposition from the grain industry that has chosen to avoid transgenic technology for the near future.

\section{Researchable issues and approaches to increase use of plant products in aquafeeds}

\section{Processing and techniques to enhance nutrient digestibility/nutritional value and quality}

Feed-processing methods have been used for many years to improve the physical characteristics and nutritional value of feeds, and the effects of different manufacturing methods are well known (Booth, Allan \& Warner-Smith 2000; Cheng \& Hardy 2003b; Venou, Alexis, Fountoulaki, Nengas, Apostolopoulou \& Castritsi-Cathariou 2003). Cooking extrusion, for example, increases carbohydrate digestibility (Allan \& Booth 2004) and produces a more durable pellet that can be controlled to make the pellet float or sink (Barrows \& Hardy 2001). Pre-processing refers to treatment of specific ingredients before mixing the ingredients together into a complete feed. Routine 
pre-processing of SBM reduces the level of trypsin inhibitors. Other antinutrients (i.e. oligosaccharides, fibre, phytate), however, are still present in SBM, and other plant ingredients, after traditional pre-processing has occurred and thus can have negative effects on fish (Olsen, Myklebust, Kryvi, Mayhew \& Ringo 2001). To increase the nutritional value of plantderived ingredients for fish, pre-processing of ingredients using both biological enhancement and mechanical modification are being explored.

Biological enhancement involves the use of microorganisms to modify the chemical composition of the ingredient. Yeast, bacterial and fungal fermentations have been investigated and current results demonstrate great potential for removing antinutrients and adding essential nutrients such as protein and amino acids (Mukhopadhyay \& Ray 1999; Bairagi, Gosh, Sen \& Ray 2004). The overall goal of these processes is to increase protein concentration and decrease the levels of antinutrients. Removal of the exotic or fermentable carbohydrates and phytate is well within the capabilities of this approach $(\mathrm{Ng}$, Lim, Lim \& Ibrahim 2002; Skrede, Storebakken, Skrede, Sahlstrom, Sorensen, Shearer \& Slinde 2002). Microorganisms consume and convert carbohydrates from unavailable energy into cell mass that serves as a digestible source of both protein and energy. The type of microorganisms and plant substrates used in the fermentation will determine the nutrient and antinutrient profile of the final product. The cost of producing biologically enhanced plant products will be the primary factor affecting their use in future aquafeed formulations.

Mechanical modification of plant-derived ingredients is an extension of current pre-processing techniques. These methods can be as simple as de-hulling barley before grinding and mixing to decrease the fibre content and thus increase protein content (Hardy \& Barrows 2000). The more complex pre-processing method of air classification uses air pressure and particle density to separate dense protein particles from the lighter carbohydrate fractions and results in a product with higher nutrient levels (Thiessen, Campbell \& Tyler 2003; Thiessen, Campbell \& Adelizi 2003). Rice protein is currently being commercially concentrated from approximately $12-70 \%$ protein using air classification. The protein concentration of barley can be doubled from $12 \%$ to $25 \%$ using air classification and this product is also currently commercially available. Other methods to increase nutrient and decrease antinutrients are also being developed and evaluated (Kim, Flores, Chung \& Bechtel 2003). Pro- tein concentrates and isolates from wheat, soy and canola are commercially available, but are currently relatively expensive for use in aquafeeds. As with biologically enhanced proteins, the final cost of the product will determine the effectiveness and commercial application of the process.

\section{Augmenting nutritional quality through genetic manipulations of plants}

The nutrient and antinutrient profiles of plant products are currently not ideal for aquafeeds. Fortunately, it is possible to change specific traits of grains, such as protein and oil content, through breeding and genetic manipulation. Genomic and genetic studies have determined the molecular mechanisms involved with the expression of different nutrient traits. Knowledge from those studies, coupled with modern technologies of genetic and molecular biology, provides powerful tools for breeders and geneticists to manipulate plants more quickly and efficiently to achieve desired traits. In the last decade, genetic manipulations have changed, as have the potential to further improve several specific nutrients in seeds. Examples of changes in several important antinutrients and nutrients are listed below.

\section{Low phytic acid mutations}

Phytic acid is the major form of phosphorus, representing $60-80 \%$ of the total phosphorus in mature seeds and is not usable by monogastric animals. Low phytic acid (up to $75 \%$ reduction in seed) but high free-phosphorus genetic materials have been identified in barley, maize, wheat, rice and soybean through mutations (Dorsch, Cook, Young, Anderson, Bauman, Volkmann, Murthy \& Raboy 2003). This low phytic acid germplasm is being used in breeding programmes to produce commercially viable cultivars that will help reduce phosphorus discharge from animal production units. The first low phytic acid mutations in wheat did reduce the amount of phytic acid by $30 \%$ or more while increasing the concentration of inorganic phosphorus in the grain (Guttieri et al. 2004). However, wheat appears to differ from other cereals in having significant genetic variation among adapted cultivars for the enzyme phytase, which degrades phytic acid. Previous studies have reported a greater than threefold difference in phytase activity among limited sub-sets of high-yielding cultivars (Okot-Kotber, Yong, Bagorogoza \& Liavoga 2003). Unpublished work at the University of Idaho has found 
similar activities among spring wheat cultivars and breeding lines adapted to the Northern United States (M. J. Guttieri \& D. Peterson, pers. comm.). Other genetic manipulations in wheat mineral composition include selection for high iron and high calcium concentrations.

\section{High lysine genetic materials}

Lysine is an EAA for animals that is often limiting in plant feedstuffs. Crops with high lysine content are of greater value, but plants in the grass family generally have low lysine content. However, genetic studies have identified high lysine mutations in corn and barley where the lysine level is increased up to $150 \%$. More recent studies have found the modifier genes of the well-known opaque-2 phenotype in maize. Plants carrying the modifier genes produce normal corn seeds with the same high level of lysine as that in the opaque-2 mutation (Gibbon \& Larkins 2005). Equally exciting progress has occurred in the successful manipulation of the genetic pathway of lysine catabolism for high lysine accumulation in Arabidopsis by disruption of the gene in that pathway (Stepansky, Yao,Tang \& Galili 2004). The same genetic approach could be adapted in all other crops for high lysine production.

\section{$\beta$-glucan manipulation}

Researchers at the USDA/ARS National Small Grains Germplasm Research Facility (Aberdeen, ID, USA) have obtained barley germplasm with $\beta$-glucan levels ranging from $1.5 \%$ to over $10.0 \%$ through breeding selection and chemical mutation. These materials are being incorporated into elite lines for various levels of $\beta$-glucan. Both low and high $\beta$-glucan lines may satisfy the needs of direct use and industry processing by-products for aquafeed production.

\section{High-oil cereal crops}

Quantitative trait loci controlling oil content have been identified in cereal maize in which oil content could approach $20 \%$ by selection (Laurie, Chasalow, LeDeaux, McCarroll, Bush, Hauge, Lai, Clark, Rocheford \& Dudley 2004). Quantitative trait loci identified in maize may help oil improvement in other cereal crops as well.

\section{Starch-structure manipulation}

The level of different starch structures such as amylose and amylopectin can be changed according to the requirement of aquafeeds through better understanding of the genes influencing starch biosynthetic pathways (Morell \& Myers 2005). In wheat grain, modification of starch to lower amylose content to produce amylose-free wheat starch (sometimes called 'waxy') is genetically possible through accumulation of three mutant forms of the granule-bound starch synthase gene. The first germplasm lines with amylase-free starch are widely available (Graybosch, Souza \& Berzonsky 2003) and the first commercial amylose-free starch cultivars are now reaching the marketplace. Development of high-amylose starch wheat cultivars is also possible (Yamamori, Fujita, Hayakawa \& Matsuki 2000). However, cultivar development in this area is less advanced than the development of cultivars with amylose-free starch. Modifications of starch can alter the functional properties and the digestibility of the starch.

\section{Increased micronutrient content}

Genes regulating micronutrients such as antioxidative compounds (like vitamin E) have been identified in Arabidopsis (Capell \& Christou 2004). That discovery may allow enhancement of such traits in crops for the possible benefit of fish.

\section{Enhancing utilization by genetic selection of fish}

Evaluation of genotype by diet interactions in aquaculture species for specific dietary components has only recently begun on a limited basis. Initial studies have examined such species as sea bream, rainbow trout and Atlantic salmon (Vivas, Sanchez-Vazquez, Garcia \& Madrid 2003; Overturf, Bullock, LaPatra \& Hardy 2004). Because of the high-protein diet these species consume in the wild, commercial diets have relied heavily on fish meal and fish oil as protein and energy sources. Other omnivorous fish species such as tilapia and catfish have demonstrated a greater proclivity for utilizing plant feedstuffs and carbohydrate for energy but little research has been performed on these species in regard to alternative dietary selection. Furthermore, a large number of aquaculture species have only recently become domesticated and as such most of the initial research with these species has involved general determination of their dietary requirements. Because of the great diversity of species that may be cultured, the physiology and metabolism of these organisms varies substantially. As such, this necessitates that every 
species be evaluated individually for its optimal nutrient requirements. When these are known, evaluation of diversity within the species for utilization of specific nutrient components can be performed and estimates made regarding improvement by a selection programme. However, in other animal systems, the effects of dietary changes on specific physiological parameters have been studied. For example, diet by strain differences has been shown in cattle and poultry (Wahstrom, Tauson \& Elwinger 1998; Roche, Kolver, de Veth \& Napper 2001; Coffey, Simm, Oldham, Hill \& Brotherstone 2004; Jones, Zaczek, MacLeod \& Hocking 2004) and this has been more specifically linked to individual genes in work performed with murine and fish models such as medaka, Oryzias latipes (Corva \& Medrano 2000; Kaput, Klein, Reyes, Kibbe, Cooney, Jovanovic, Visek \& Wolff 2004; Hostetler, Collodi, Devlin \& Muir 2005).

In aquaculture, there have been very few studies attempting to discern the effects of genotype on nutrient utilization. Initial studies have focused on replacement of fish meal protein with that from plants, typically using refined feedstuffs. Hence, the protein component as well as antinutritional factors and other factors have been altered, so what is being evaluated at this level is the lack of hormones and other by-products found in fish meal with that of the replacement protein. This severely limits our ability to interpret the effect of unrefined materials on the animal's metabolism and physiology. All other dietary components relating to amino acid levels, nitrogen levels, etc., are held constant. Also, the high cost of production of refined diets makes them of limited value for aquaculture feeding practices. Of greater interest is the determination of whether carnivorous fish that have been evolutionary selected to utilize protein as their main energy source can be selected for improved utilization of plant material. In the past, diet studies were roughly correlated by relating growth indices such as weight gain, feed efficiency, growth rate, digestibility and proximate analysis of whole fillets to variable changes of dietary components. With the recent impetus of genomics, and the increasing amount of sequence information available, an improved understanding of cellular signalling, and the role of genes and proteins in pathways, now several research groups are beginning to characterize what is occurring in the animal not only physiologically but also at the cellular and genomic levels.

Several vertebrate genomes have been completely sequenced and this allows for the retrieval of homo- logous sequences from previously uncharacterized genomes. With the availability of this information, the correlations of biochemical information with genetic and molecular data will be very useful in providing improved insight into the functions of unknown genes or systems responses to nutrient changes. This research is being pursued even more intensively via the use of microarrays where scientists can now screen for the expression of thousands of genes in single experiments. This will revolutionize how nutritionists evaluate diets in that now they can relate precise dietary changes with specific physiological pathways that are being modulated by nutritional differences.

Future work requiring genomic information will focus on the current most highly characterized species such as Atlantic salmon, channel catfish and rainbow trout and may incorporate information gained from other highly developed research species such as zebrafish, Brachydanio rerio, fugu fish, Takifugu flavidus and medaka.

\section{Optimizing bioactive compounds}

Several plant feedstuffs contain bioactive compounds that may have positive or negative effects on aquatic animals and thus their concentrations in aquafeeds must be adjusted accordingly. For example, cottonseed is a source of many phytochemicals such as flavonoids. Quercetin, a common flavonoid in plants, was measured at concentrations from 1320 to $1560 \mathrm{mg} \mathrm{kg}^{-1}$ in three different cottonseed preparations (Lee et al. 2002). Many positive functions have been attributed to quercetin upon its intake by humans and it has also drawn attention for decades due to its beneficial effects as an antioxidant agent in fish oil storage (Martinez Nieto, Garrido Hoyos, Camacho Rubio, Garcia Pareja \& Ramos Cormenzana 1993). Owing to such antioxidant activities, this flavonoid also has been proven efficacious against various pathological conditions such as cancer, cardiovascular disease and other oxidative stresses (Formica \& Regelson 1995). Despite the ubiquitous occurrence of quercetin in feedstuffs such as CSM (Shahidi \& Naczk 1995), and thus possible ingestion by fish (Rinchard, Lee, Czesny, Ciereszko \& Dabrowski 2003), little is known of its nutritional role in formulated aquafeeds. The only available report indicates that quercetin is not overly toxic to rainbow trout when fed for several months at high levels (Plakas, Lee \& Wolke 1985). Some other reports, 
however, claimed high toxicity of quercetin to the reproductive system of fish upon external exposure (Weber, Kiparissis, Hwang, Niimi, Janz \& Metcalfe 2002).

Other bioactive compounds such as many of the proteins found in SBM must be characterized as to the immunological basis of their food-intolerance activity to determine whether the same proteins induce intolerance in diverse species of fish. If soy proteins are identified that induce immunological response in fish species of commercial interest, varieties lacking those proteins could be stacked with other traits desirable to the aquaculture industry. Specific steps to accomplishing these goals will be: (1) identify specific proteins that induce soybean-food intolerance in fish; (2) determine whether the adverse reactions are due to the physical presence of the proteins or dependent on their biological activity; and (3) determine the extent of intolerance-response commonality among farmed fish species. On the basis of this approach, a strategy to mitigate food intolerance by altering seed protein content may create the opportunity to use renewable plant-based feedstuffs as substitutes for fish meal. To accomplish this, team resources including laboratories with experience in fish growth and physiology will be needed along with other laboratories experienced in analyzing adverse immunological reactions and having the capability to modify the protein component of the feedstuff.

\section{Using pre- and probiotic compounds to enhance utilization}

It has been documented in a number of food animals that their gastrointestinal microbiota plays important roles in affecting the nutrition and health of the host organism. Thus, various means of altering the intestinal microbiota to achieve favourable effects such as enhancing growth, digestion, immunity and disease resistance of the host organism have been investigated in various terrestrial livestock as well as in humans. Dietary supplementation of prebiotics, which are classified as non-digestible food ingredients that beneficially affect the host by stimulating growth and/or activity of a limited number of health-promoting bacteria such as Lactobacillus and Bifidobacter spp. in the intestine, while limiting potentially pathogenic bacteria such as Salmonella, Listeria and Escherichia coli, have been reported to favourably affect various terrestrial species. However, such information is extremely limited to date for aquatic organisms. Effects of probiotics, defined as live microbial-feed supplements, on gastrointestinal microbiota have been studied in some fish, but the primary application of microbial manipulations in aquaculture has been to alter the composition of the aquatic medium. In general, the gastrointestinal microbiota of fish including those produced in aquaculture has been poorly characterized, especially the anaerobic microbiota. Therefore, more detailed studies of the microbial community of cultured fish are needed to potentially enhance the effectiveness of prebiotic and probiotic supplementation.

\section{Monitoring effects of plant feedstuffs on fish product quality and consumer health}

Success or failure in any commercial aquaculture endeavour ultimately depends on repeat purchasing by consumers, whether at the retail, wholesale or food service level. Aquatic foods market research consistently indicates that product quality is the single most important attribute effecting fish-purchasing behaviour. Given the recent onslaught of negative media attention to farm-raised fish, consumers are also more focused on the potential health effects associated with fish consumption. As we move forward toward increasing the use of plant products in aquafeeds, the effects of these newly formulated diets on fish product quality and consumer health must be evaluated.

Although quality is a complex issue, for the purposes of this paper it will refer primarily to the colour, flavour, texture and nutrient composition of the fish product. Numerous studies have reported that all of the previous attributes, as well as shelf-life stability of fish fillets, can be affected by diet composition. An overwhelming majority of the studies, particularly those that have included the use of sensory methods to evaluate quality, have focused on salmonids, primarily rainbow trout and Atlantic salmon. Nonsalmonid species sporadically evaluated for dietary influence on sensory quality include Gulf sturgeon, Acipenser sp. Linnaeus, hybrid striped bass, white amur, Ctenopharyngodon idella Valenciennes, turbot, barramundi, perch, tilapia and channel catfish. Flavour, colour, odour and/or texture were significantly affected by diet in about half the studies reported. Given the physiological, nutritional, environmental and compositional differences among aquacultured finfish, conclusions reached about the product quality of one species cannot be automatically applied to another. Further research is needed to clarify the 
influence of dietary ingredients on quality of each aquaculture species of interest.

Three different methods of sensory analysis have typically been used to characterize the organoleptic quality of fish fillets in the studies indicated above: descriptive analysis, difference testing and consumer-acceptability testing. The most sophisticated of these, descriptive analysis, uses trained sensory panelists to profile individual flavour, odour and texture descriptors in the fish, and to rate them for their intensity. Different flavour attributes, such as nutty, sweet, fishy, painty or grassy, have been used to describe the effects of dietary ingredients on the specific flavour characteristics of fish from different dietary treatments. Although this type of information can be extremely useful in the later stages of productquality evaluation and modification, for the purposes of initial evaluation of plant-based ingredients in aquafeeds, untrained consumer panels should be utilized. Trained panelists have been reported to discern differences among samples that average consumers cannot. Research in this field should attempt to answer two questions that have important marketing ramifications: (1) can the average consumer tell the difference between fillets from fish reared on the plant-based diet versus a fish meal control diet, and (2) does the average consumer prefer fish from one dietary treatment over the other?

While numerous studies have evaluated the effects of various alternative plant proteins on fish growth and feed efficiency, relatively few have monitored the dietary influence on fish quality. However, a review of 15 studies, which investigated the effects of various plant proteins, including SBM, SPC, soy flour, corn gluten, wheat gluten, peanut meal, canola meal, extruded peas, lupin seed meal and CSM, on fillet quality, indicates that product quality was significantly influenced by protein source in about $40 \%$ of the studies. Colour, as measured by instrumental and sensory methods, was the attribute most influenced by protein source. Texture and flavour were significantly affected by protein source in some cases, particularly when large substitutions were made. However, other studies in which $30-60 \%$ of the diet was composed of plant protein meals reported no differences in consumer acceptability among fillets. Clearly, the effects of plant protein meals, particularly those subjected to various degrees of concentration and/or isolation, on product quality require further investigation.

Two important areas related to consumer health that should be addressed with regard to utilization of plant products in aquafeeds are $\omega-3$ fatty acid level and possible PCB contamination in fillets. Because fatty acid composition of fish fillets is related to the fatty acid composition of the diet, fish fed primarily plant-based diets contain lower levels of $\omega$-3 fatty acids. Given that consumers are becoming more interested in the health benefits of these fatty acids, future research should include evaluating the effects of finishing diets rich in $\omega-3$ fatty acids on fatty acid profile and sensory quality of the fillets. As PCB contamination of farmed fish arises primarily from fish oil, methods need to be developed that enrich the $\omega-3$ content of the fillet without increasing contaminant levels. Although the risks of organochlorine contamination from farmed fish are open to debate, consumers are aware of this issue, which may affect their purchasing behaviour.

\section{Enhancing palatability of plant feedstuffs}

Fish show distinct taste preferences in basic studies of taste and smell. In a recent review paper (Kasumyan \& Doving 2003), the state of the art is summarised as follows: "Fish taste preferences are highly species specific, and the differences among fish species are apparent when comparing the width and composition of spectra for both the stimulants and the deterrents. What is evident is that there is a strong similarity in the taste preferences between geographically isolated fish populations of the same species, and that taste preferences are similar in males and females, although at the individual level it may vary dramatically among conspecifics. What is noteworthy is that taste responses are more stable and invariable for highly palatable substances than for substances with a low level of palatability. There is a good correspondence between development of the gustatory system in fish ontogeny and its ability to discriminate the taste properties of food items. There is also a correspondence between oral and extraoral taste preferences for a given species; however, there is no correlation between smell and taste preferences. Taste preferences in fish show low plasticity (in relation to the diet), appear to be determined genetically and seem to be patroclinous. Fish-feeding motivation and various environmental factors like water temperature and pollutants such as heavy metals and low $\mathrm{pH}$ water may shift fish taste preferences. Comparisons between bioassay and electrophysiological data show that palatability is not synonymous with excitability in the gustatory system:

The methodologies and expertise gained in basic studies should be used to characterize the taste 
elements of plant feedstuffs and how processing alters palatability. Research regarding palatability of various feedstuffs may indicate why feed intake is often reduced when certain feedstuffs are included in fish diets and suggest how processing may be conducted to optimize palatability. The fact that palatability is the sum of many dietary characteristics and that there is a strong interaction between taste and nutritional quality should be reflected in the experimental designs. Such interactions have not gained much attention in research so far, either in fish nutrition or in the nutrition of other animals.

\section{Metabolomics}

Metabolomics is the study of the metabolic profile of a given cell, tissue, fluid, organ or organism at a given point in time. The metabolome represents the end products of gene expression. Thus, mRNA gene expression data and proteomic analyses do not tell the whole story of what might be happening in a cell (mRNA gene transcripts do not necessarily reflect either concentration or activity of a gene product in a cell) and do not account for post-translational modifications. Of all the feedstuffs described in this document, soybean is the most widely studied with its chemical composition of the major nutrient components as well as the NSP having been described in detail and variability being well characterized. Also the contents of a number of biologically active components, some of which belong to the rather ill-defined group of antinutrients, have been described to a certain extent. However, a wide range of components are still unknown. The possibility that some of these components may have biological effects of positive or negative character is very likely. Despite investigation of the adverse effects of soybeans in salmonids for two decades, the causing agent(s) has not been found. The component may well be among the unidentified compounds. Developments in instrumentation and chemical approaches over the last few years have greatly improved.

It appears that to describe and predict the nutritional value of soybeans and other plant feedstuffs on the one hand, and possible adverse antinutrient and toxic effects on the other hand, it is imperative to gain detailed chemical information with regard to the secondary metabolites (Becker \& Makkar 1999; Francis et al. 2001; Overturf et al. 2003; Pezzato, deOliveira, Dias, Barros \& Pezzato 2004; Ulloa, van Weerd, Huisman \& Verret 2004). Metabolic profiling and the identification of single volatile, semi-volatile and flavour compounds may lead the way to unknown compounds that might impact digestibility of these products and influence the physiology, growth and health of farmed fish (Johnsen \& Dupree 1991; Grigorakis, Taylor \& Alexis 2001). The analytes of interest likely belong to the following chemical groups: aliphatic hydrocarbons and their derivatives, terpenes, phenols, N- and S-containing compounds (e.g. alkaloids, glucosinolates) (Rohloff 2003, 2004). Analytical approaches have been reviewed by Wilkes, Conte, Yonkyoung, Holcomb, Sutherland and Miller (2000) and Bino, Hall, Fiehn, Kopka, Saito, Draper, Nikolau, Mendes, Roessner-Tunali, Beale, Trethewey, Lange, Wurtele and Sumner (2004).

A combination of analytical platforms (e.g., GCMS, LC-MS-MS) may be used to evaluate the metabolic composition of various plant feedstuffs. This approach can be used interactively to evaluate the composition of these feedstuffs and fractions with differential levels of antinutrients and to identify specific antinutrients. These plant feedstuffs could be fractionated by extractions and preparatory HPLC, and the resultant fractions could be tested for antinutrient activity (in collaboration with fishery biologists), metabolic composition and protein components. Statistical analysis would be used to identify metabolic correlates of antifeedant activity. Antifeedant fractions could be further fractionated and the resultant fractions tested for antinutrient activity and metabolic composition.

\section{Conclusions and recommendations}

On the basis of the information reviewed in this document, specific strategies and a variety of techniques have been identified to optimize the nutritional composition of plant feedstuffs and limit potentially adverse effects of bioactive compounds. A coordinated research effort needs to be developed through strategic planning to further evaluate and refine various means of improving the nutritional value of plant feedstuffs for increasing their use in aquaculture. Such efforts will result in reducing the dependence on animal feedstuffs and increasing the sustainability of aquaculture.

\section{References}

Alford B.B., Liepa G.U. \& Vanbeber A.D. (1996) Cottonseed protein: what does the future hold? Plant Foods Human Nutrition 49, 1-11. 
Allan G.L. \& Booth M.A. (2004) Effects of cooking extrusion processing on digestibility of peas, lupins, canola meal and soybean meal in silver perch Bidyanus bidyanus (Mitchell) diets. Aquaculture Research 35, 981-991.

Allan G.L. \& Rowland S.J. (1994) The use of Australian oilseeds and grain legumes in aquaculture diets. In: The Third Asian Fisheries Forum (ed. by L.M. Chou, A.D. Munro, T.J. Lam, T.W. Chen, L.K.K. Cheong, J.K. Ding, K.K. Hooi, H.W. Khoo, V.P.E. Phang, K.F. Shim \& C.H. Tan), pp. 667-670. Asian Fisheries Society, Manila, Philippines.

Allan G.L., Parkinson S., Booth M.A., Stone D.A.J., Rowland S.J., Frances J. \& Warner-Smith R. (2000) Replacement of fishmeal in diets for Australian silver perch, Bidyanus bidyanus: digestibility of alternative ingredients. Aquaculture 186, 293-310.

Almirall M., Francesch M., Perez-Vendrell A.M., Brufau J. \& Esteve-Garcia E. (1995) The differences in intestinal viscosity produced by barley and $\beta$-glucanase alter digesta enzyme activities and ileal nutrient digestibilities more in broiler chicks than in cocks. Journal of Nutrition $\mathbf{1 2 5}$, 947-955.

Anonymous (1992) Raw Material Compendium: A Compilation of Worldwide Data Sources, 1st edn. Novus International, St. Louis, MO, USA, 511pp.

Bairagi A., Gosh K.S., Sen S.K. \& Ray A.K. (2004) Evaluation of the nutritive value of Leucaena leucocephala leaf meal, inoculated with fish intestinal bacteria Bacillus subtillis and Bacillus circulans in formulated diets for roho, Labeo rohita (Hamilton) fingerlings. Aquaculture Research 35 , 436-446.

Bakke McKellep A.M., Press C.M., Baeverfjord G., Krogdahl K. \& Landsverk T. (2000) Changes in immune and enzyme histochemical phenotypes of cells of the intestinal mucosa of Atlantic salmon (Salmo salar L) with soybean-meal induced enteritis. Journal of Fish Disease 23, 115-127.

van Barneveld R.J. (1999) Understanding the nutritional chemistry of lupin (Lupinus spp.) seed to improve livestock production efficiency. Nutrition Research Reviews 12, 203-230.

Barrows F.T. \& Hardy R.W. (2001) Nutrition and feeding. In: Fish Hatchery Management (ed. by G. Wedemeyer), 2nd edn, pp. 483-558. John Wiley \& Sons, New York, NY, USA.

Becker K. \& Makkar H.P.S. (1999) Effects of dietary tannic acid and quebracho tanninnext term on growth performance and metabolic rates of common carp (Cyprinus carpio L.). Aquaculture 175, 327-335.

Bedford M.R. \& Classen H.L. (1992) Reduction of intestinal viscosity through manipulation of dietary rye and pentosanase concentrations is effected through changes in carbohydrate composition of the intestinal aqueous phase and results in improved growth rate and food conversion efficiency of broiler chicks. Journal of Nutrition 122 , 560-569.

Bennetau-Pelissero C., Breton B., Bennetau B., Corraze G., LeMenn F., Davail-Cuisset B., Helou C. \& Kaushik S.J. (2001) Effect of genistein-enriched diets on the endocrine process of gametogenesis and on reproduction efficiency of the rainbow trout Oncorhynchus mykiss. General and Comparative Endocrinology 121, 173-187.

Bennetau-Pelissero C., Latonnell K.G., Lamonthe V., Shinkaruk-Poix S. \& Kaushik S.J. (2004) Screening for estrogenic activity of plant and food extracts using in vitro trout hepatocyte cultures. Phytochemical Analysis 15, $40-45$.

Bergh M.O., Razdan A. \& Aman P. (1999) Nutritional influence of broiler chicken diets based on covered normal, waxy and high amylose barleys with or without enzyme supplementation. Animal Feed Science and Technology 78, 215-226.

Bæverfjord G. \& Krogdahl Å. (1996) Development and regression of soybean meal induced enteritis in Atlantic salmon distal intestine. A comparison with the intestines of fasted fish. Journal of Fish Disease 19, 375-387.

Bino R.J., Hall R.D., Fiehn O., Kopka J., Saito K., Draper J., Nikolau B.J., Mendes P., Roessner-Tunali U., Beale M.H., Trethewey R.N., Lange B.M., Wurtele E.S. \& Sumner L.W. (2004) Potential of metabolomics as a functional genomics tool. Trends in Plant Science 9, 418-425.

Booth M.A., Allan G.L. \& Warner-Smith R. (2000) Effects of grinding, steam conditioning and extrusion of a practical diet on digestibility and weight gain of silver perch, Bidyanus bidyanus. Aquaculture 182, 287-299.

Bregitzer P. (2005) ARS barley research at Aberdeen; progress in research, product development and goals. Proceedings of the 35th Barley Improvement Conference, Charleston, SC, pp. 48-53.

Bureau D.P., Harris A.M. \& Cho C.Y. (1998) The effects of purified alcohol extracts from soy products on the feed intake and growth of Chinook salmon (Oncorhychus tshawytscha) and rainbow trout (Oncorhynchus mykiss). Aquaculture 161, 27-43.

Bushuk W. \& Wrigley C.W. (1974) Proteins: composition, structure and function. In: Wheat: Production and Utilization (ed. by G.E. Inglett), AVI, Westport, CT, USA, 119pp.

Cai Y. \& Burtle G.J. (1996) Methionine requirement of channel catfish fed soybean meal-corn-based diets. Journal of Animal Science 74, 514-521.

Capell T. \& Christou P. (2004) Progress in plant metabolic engineering. Current Opinion in Biochemistry 15, 148 154.

Chen J.C. \& Chen K.-W. (1997) Oxygen uptake and ammonia$\mathrm{N}$ excretion of juvenile Penaeus japonicus during depuration following one-day exposure to different concentrations of saponin at different salinity levels. Aquaculture 156, $77-83$.

Cheng Z.J. \& Hardy R.W. (2002) Effect of microbial phytase on apparent nutrient digestibility of barley, canola meal, wheat and wheat middlings, measured in vivo using rainbow trout (Oncorhynchus mykiss). Aquaculture Nutrition $\mathbf{8}$, 271-277.

Cheng Z.J. \& Hardy R.W. (2003a) Effects of extrusion processing of feed ingredients on apparent digestibility 
coefficients of nutrients for rainbow trout (Oncorhynchus mykiss). Aquaculture Nutrition 9, 77-83.

Cheng Z.J. \& Hardy R.W. (2003b) Effects of extrusion and expelling processing, and microbial phytase supplementation on apparent digestibility coefficients of nutrients in full-fat soybeans for rainbow trout (Oncorhynchus mykiss). Aquaculture 218, 501-514.

Choct M., Hughes R.J., Wang J., Bedford M.R., Morgan A.J. \& Annison G. (1996) Increased small intestinal fermentation is partly responsible for the anti-nutritive activity of non-starch polysaccharides in chickens. British Journal of Poultry Science 37, 609-621.

Coffey M.P., Simm G., Oldham J.D., Hill W.G. \& Brotherstone S. (2004) Genotype and diet effects on energy balance in the first three lactations of dairy cows. Journal of Dairy Science 87, 4318-4326.

Corva P.M. \& Medrano J.F. (2000) Diet effects on weight gain and body composition in high growth (hg/hg) mice. Physiological Genomics 3, 17-23.

Cox T.S., Shogren M.D., Sears R.G., Martin T.J. \& Bolte L.C. (1989) Genetic improvement in milling and baking quality of hard red winter wheat cultivars, 1919 to 1988. Crop Science 29, 626-631.

Dabrowski K., Rinchard J., Lee K.-J., Blom J.H., Ciereszko A. \& Ottobre J. (2000) Effects of diets containing gossypol on reproductive capacity of rainbow trout (Oncorhynchus mykiss). Biology of Reproduction 62, 227-234.

Davies S.J. (1985) The role of dietary fibre in fish nutrition. In: Recent Advances in Aquaculture, Vol. 2 (ed. by J.F. Muir \& R.J. Roberts), pp. 219-249. Westview Press, Boulder, CO, USA.

Dias J., Rueda-Jasso R., Panserat S., Conceicao L., Gomes E. \& Dinis M. (2004) Effect of dietary carbohydrate-to-lipid ratios on growth, lipid deposition and metabolic hepatic enzymes in juvenile Senegalese sole (Solea senegalensis, Kaup). Aquaculture Research 35, 1122-1130.

Dorsa W.J., Robinette H.R., Robinson E.H. \& Poe W.E. (1982) Effects of dietary cottonseed meal and gossypol on growth of young channel catfish. Transactions of the American Fisheries Society 111, 651-655.

Dorsch J.A., Cook A., Young K.A., Anderson J.M., Bauman A.T., Volkmann C.J., Murthy P.P.N. \& Raboy V. (2003) Seed phosphorus and inositol phosphate of barley low phytic acid genotypes. Phytochemistry 62, 691-706.

Drackley J.K. (2000) Nutritional constraints to use of soy products by animals. In: Soy in Animal Nutrition (ed. by J.K. Drackley), pp. 127-170. Federated Animal Society, Savoy, IL, USA.

D’Souza N., Skonberg D.I., Camire M.E., Guthrie K.E., Malison J. \& Lima L. (2005) Influence of dietary genistein levels on tissue genistein deposition and on the physical, chemical, and sensory quality of rainbow trout, Oncorhynchus mykiss. Journal of Agriculture and Food Chemistry $\mathbf{5 3}$, $3631-3636$.

Duke J.A. (1981) Handbook of Legumes of World Economic Importance. Plenum Press, New York, USA:, 345pp.
Erlund I., Kosonen T., Alfthan G., Maenpaa J., Perttunen K., Kenraali J., Parantainen J. \& Aro A. (2000) Pharmacokinetics of quercetin from quercetin aglycone and rutin in healthy volunteers. European Journal of Clinical Pharmacology 56, 545-553.

Fang N., Yu S. \& Badger T.M. (2004) Comprehensive phytochemical profile of soy protein isolate. Journal of Agriculture and Food Chemistry 52, 4012-4020.

FAO. (1970) Amino acid content of foods and biological data on proteins. FAO Nutritional Studies No. 24. Food and Agricultural Organization of the United Nations, Rome.

FAOSTAT. (2005) Food and Agriculture Organization of The United Nations. http://faostat.fao.org/faostat/collec tions? version $=$ ext\&hasbulk $=0 \&$ subset $=$ agriculture

FAO. State of World Aquaculture. (2006) FAO Fisheries Technical Paper. No.500. Rome, FAO, 145pp. http://www. fao.org/figis/servlet/static?dom=root\&xml=aquaculture/ regionalreviewslist.xml

Favier M.L., Bost P.E., Guittard C., Demigné C. \& Rémésy C. (1997) The cholesterol-lowering effect of guar gum is not the result of a simple diversion of bile acids toward fecal excretion. Lipids 32, 953-959.

Flores R.A., Eustace D.W. \& Hicks K.B. (2004) Experimental milling of barley samples. Meeting Abstract 2004. American Association of Cereal Chemists, San Diego, CA, USA, 19-22 September. Poster 243.

Floreto E.A.T., Baker R.C. \& Brown P.B. (2000) The effects of soybean-based diets, with and without amino acid supplementation, on growth and biochemical composition of juvenile American lobster, Homarus americanus. Aquaculture 189, 211-235.

Formica J.V. \& Regelson W. (1995) Review of the biology of quercetin and related bioflavonoids. Food and Chemical Toxicology 33, 1061-1080.

Fowler L.G. (1980) Substitution of soybean and cottonseed products for fish meal in diets fed to chinook and coho salmon. The Progressive Fish-Culturist 42, 87-91.

Francis G., Makkar H.P.S. \& Becker K. (2001) Antinutritional factors present in plant-derived alternate fish feed ingredients and their effects in fish. Aquaculture 199, 197-227.

Francis G., Makkar H.P.S. \& Becker K. (2005) Quillaja saponins - a natural growth promoter for fish. Animal Feed Science Technolology 121, 147-157.

Furuya W.M., Pezzato L.E., Barros M.M., Pezzato A.C., Furuya V.R.B. \& Miranda E.C. (2004) Use of ideal protein concept for precision formulation of amino acid levels in fish-meal free diets for juvenile Nile tilapia (Oreochromis niloticus L.). Aquaculture Research 35, 1110-1116.

Garcia-Abiado M.A., Mbahinzireki G., Rinchard J., Lee K.J. \& Dabrowski K. (2005) Effect of diets containing gossypol on blood parameters and spleen structure in tilapia, Oreochromic sp., reared in a recirculating system. Journal of Fish Diseases 27, 359-368.

Gibbon B.C. \& Larkins B.A. (2005) Molecular genetic approaches to developing quality protein maize. Trends in Genetics 21, 227-233. 
Glencross B.D., Boujardand T. \& Kaushick S.J. (2003) Influence of oligosaccharides on the digestibility of lupin meals when fed to rainbow trout, Oncorhynchus mykiss. Aquaculture 219, 703-713.

Glencross B., Curnow J., Hawkins W., Kissil G.W. \& Peterson D. (2003) Evaluation of the feed value of a transgenic strain of the narrow-leaf lupin (Lupinus angustifolius) in the diet of the marine fish, Pagrus auratus. Aquaculture Nutrition 9, 197-206.

Glencross B.D., Carter C.G., Duijster N., Evans D.R., Dods K., McCafferty P., Hawkins W.E., Maasand R. \& Sipsas S. (2004) A comparison of the digestibility of a range of lupin and soybean protein products when fed to either Atlantic salmon (Salmo salar) or rainbow trout (Oncorhynchus mykiss). Aquaculture 237, 333-346.

Glencross B., Evans D., Hawkins W. \& Jones B. (2004) Evaluation of dietary inclusion of yellow lupin (Lupinus luteus) kernel meal on the growth, feed utilisation and tissue histology of rainbow trout (Oncorhynchus mykiss). Aquaculture 235, 411-422.

Graybosch R.A., Souza E. \& Berzonsky W. (2003) Registration of 19 waxy spring wheat germplasm. Crop Science 43, 1491-1492

Grigorakis K.,Taylor K.D.A. \& Alexis M.N. (2001) Organoleptic and volatile aroma compounds comparison of wild and cultured gilthead sea bream (Sparus aurata): sensory differences and possible chemical basis. Aquaculture 225, 109-119.

Guillon F. \& Champ M.M.J. (2002) Carbohydrate fractions of legumes: uses in human nutrition and potential for health. British Journal of Nutrition 88, S293-S306.

Guttieri M.J., Bowen D., Dorsch J.A., Souza E. \& Raboy V. (2004) Identification and characterization of a low phytic acid wheat. Crop Science 44, 418-424.

Hardy R.W. \& Barrows F.T. (2000) Diet formulation and manufacturing. In: Fish Nutrition (ed. by J.E. Halver \& R.W. Hardy), 3rd edn, pp. 505-600. Academic Press, New York, NY, USA.

Herman E.M. (2004) Allergenic responses to legume proteins. In: Genomics for Legume Crops (ed. by C. Brummer \& R. Wilson), pp. 326-347. American Oil Chemists Society Press, Champaign, IL, USA.

Herman R.L. (1970) Effects of gossypol on rainbow trout (Salmo gairdneri). Journal of Fish Biology 2, 293-297.

Hickling D. (2003) Canadian Feed Peas, Industry Guide. Pulse Canada, Winipeg, MB, Canada, 35pp.

Hicks K.B., Taylor F., Kohout K.M., Kurantz M.J.,Thomas J.L., O'Brien D.J., Johnston D., Flores R.A., Moreau R.A. \& Hoot L. (2004) Developing barley as a major feedstock for fuel ethanol production. Meeting Abstract 2004. International Fuel Ethanol Workshop \& Trade Show, 22-25 June, Session 7, Feedstocks for Ethanol Production, Madison, WI, USA.

Hostetler H., Collodi P., Devlin R. \& Muir W. (2005) Improved phytate phosphorus utilization by Japanese medaka transgenic for the Aspergillus niger phytase gene. Zebrafish 2, 19-31.
Hou Y.C., Chao P.D., Ho H.J., Wen C.C. \& Hsiu S.L. (2003) Profound difference in pharmacokinetics between morin and its isomer quercetin in rats. Journal of Pharmacology $\mathbf{5 5}$, 199-203.

van den Ingh T.S.G.A.M., Krogdahl Å., Olli J.J., Hendrix H.G.C.J.M. \& Koninkx J.G.J.F. (1991) Effects of soybean containing diets on the proximal and distal intestine in Atlantic salmon (Salmo salar): a morphological study. Aquaculture 94, 297-305.

van den Ingh T.S.G.A.M., Olli J.J. \& Krogdahl Å. (1996) Alcohol-soluble components in soybeans cause morphological changes in the distal intestine of the Atlantic salmon, Salmo salar L. Journal of Fish Disease 19, 47-53.

Jenkins P.G., Harris J.E. \& Pulsford A.L. (1991) Enhanced enteric uptake of human gamma globulin by Quil-A saponin in Oreochromis mossambicus. Fish and Shellfish Immunology 1, 279-295.

Jenkins D.J., Kendall C.W., Vuksan V., Vidgen E., Parker T., Faulkner D., Mehling C.C., Garsetti M., Testolin G., Cunnane S.C., Ryan M.A. \& Corey P.N. (2002) Soluble fiber intake at a dose approved by the US food and drug administration for a claim of health benefits: serum lipid risk factors for cardiovascular disease assessed in a randomized controlled crossover trial. American Journal of Clinical Nutrition 75, 834-839.

Johnsen P.B. \& Dupree H.K. (1991) Influence of feed ingredients on the flavor quality of farm-raised catfish. Aquaculture 96, 139-150.

Jones E., Zaczek V., MacLeod M. \& Hocking P.M. (2004) Genotype, dietary manipulation and food allocations affect indices of welfare in broiler breeders. British Journal of Poultry Science 45, 725-737.

Kaiser C.R., Bowman J.G.P., Surber L.M.M., BlakeT.K. \& Borowski J.J. (2004) Variation in apparent component digestibility of barley in the rat from the core collection of the USDA nation small grains collection. Animal Feed Science Technology 113, 97-112.

Kaput J., Klein K.G., Reyes E.J., Kibbe W.A., Cooney C.A., Jovanovic B., Visek W.J. \& Wolff G.L. (2004) Identification of genes contributing to the obese yellow Avy phenotype: caloric restriction, genotype, diet $\times$ genotype interactions. Physiological Genomics 18, 316-324.

Kasumyan A.O. \& Doving K.B. (2003) Taste preferences in fishes. Fish and Fisheries 4, 289-347.

Keembiyehetty C.N. \& Gatlin D.M. III. (1997) Performance of sunshine bass fed soybean-meal-based diets supplemented with different methionine compounds. The ProgressiveFish-Culturist 59, 25-30.

Kim Y.S., Flores R.A., Chung O.K. \& Bechtel D.B. (2003) Physical and chemical characterization of wheat flour milling co-products. Journal of Food Process Engineering 26, 469-488.

Krogdahl A. (1996) Effects of soybean antinutrients on intestinal environment, lipid hydrolysis and utilization on Atlantic salmon (Salmo salar, L). I effects of antinutrient 
on the nutritional value of legume diets. (ed. by S. Bardocs, FV. Nekrep \& A. Pusztai), Vol. 3 (pp. 74-81.

Krogdahl A. \& Holm H. (1983) Pancreatic proteinases from man, trout, rat, pig, cow, chicken, mink and fox. Enzyme activities and inhibition by soybean and lima bean proteinase inhibitors. Comparative Biochemistry and Physiology 74B, 403-409.

Krogdahl Å., Bakke-McKellep A.M. \& Baeverfjord G. (2003) Effects of graded levels of standard soya bean meal on intestinal structure, mucosal enzyme activities, and pancreatic response in Atlantic salmon (Salmo salar L). Aquaculture Nutrition 9, 361-371.

Kuz'mina VV. (1996) Influence of age on digestive enzyme activity in some freshwater teleosts. Aquaculture 148, 25-37.

Latonnelle K., Fostier A., LeMenn F. \& Bennetau-Pelissero C. (2002) Binding affinities of hepatic nuclear estrogen receptors for phytoestrogens in rainbow trout (Oncorhynchus mykiss) and Siberian sturgeon (Acipenser baeri). General and Comparative Endocrinology 129, 69-79.

Latonnelle K., LeMenn F., Kaushik S.J. \& Bennetau-Pelissero C. (2002) Effects of dietary phytoestrogens in vivo and in vitro in rainbow trout and Siberian sturgeon: interests and limits of the in vitro studies of interspecies differences. General and Comparative Endocrinology 126, 39-51.

Laurie C.C., Chasalow S.D., LeDeaux J.R., McCarroll R., Bush D., Hauge B., Lai C., Clark D., Rocheford T.R. \& Dudley J.W. (2004) The genetic architecture of response to long-term artificial selection for oil concentration in the maize kernel. Genetics 168, 2141-2155.

Lee K.J., Dabrowski K., Blom J.H., Bai S.C. \& Stromberg P.C. (2002) A mixture of cottonseed meal, soybean meal and animal byproduct mixture as a fish meal substitute: growth and tissue gossypol enantiomers in juvenile rainbow trout (Oncorhynchus mykiss). Journal of Animal Physiology and Nutrition 86, 201-213.

Lee K.J., Rinchard J., Dabrowski K., Babiak I., Ottobre J.S. \& Christensen J.E. (2006) Long-term effects of dietary cottonseed meal on growth and reproductive performance of rainbow trout: three-year study. Animal Feed Science and Technology 126, 93-106.

Levrat M.A., Moundras C., Younes H., Morand C., Demigne C. \& Rémésy C. (1996) Effectiveness of resistant starch, compared to guar gum, in depressing plasma cholesterol and enhancing fecal steroid excretion. Lipids 31, 1069-1075.

Liener I.E. (2000) Non-nutritive factors and bioactive compounds in soy. In: Soy in Animal Nutrition (ed. by J.K. Drackley), pp.127-170. Federated Animal Science Society, Savoy, IL, USA.

Linberg J.E., Arvidsson A. \& Wang J. (2003) Influence of naked barley cultivar with normal, amylose-rich or amylopectin-rich starch and enzyme supplementation on digestibility and piglet performance. Animal Feed Science and Technology 104, 121-131.

Luckett D. (2004) Lupin bean: a bitter contamination risk for sweet albus lupins. NSW Department of Primary Industries, Agnote DPI-498, 18 August 2004 (1st edn).
Lupton J.R., Robinson M.C. \& Morin J.L. (1994) Cholesterollowering effect of barley bran flour and oil. Journal of the American Dietetic Association 94, 65-70.

Mambrini M., Roem A.J., Cravedi J.P., Lalles J.P. \& Kaushik S.J. (1999) Effects of replacing fish meal with soy protein concentrate and of DL-methionine supplementation in high-energy, extruded diets on the growth and nutrient utilization of rainbow trout, Oncorhynchus mykiss. Journal of Animal Science 77, 2990-2999.

Manach C., Morand C., Crespy V., Demigne C., Texier O., Regerat F. \& Remesy C. (1998) Quercetin is recovered in human plasma as conjugated derivatives which retain antioxidant properties. FEBS Letter 426, 331336.

Manach C., Texier O., Morand C., Crespy V., Regerat F., Demigne C. \& Remesy C. (1999) Comparison of the bioavailability of quercetin and catechin in rats. Free Radicals in Biology and Medicine 27, 1259-1266.

Martin J.H., Leonard W.H. \& Stamp D.L. (1976) Principles of Field Crop Production, 3rd edn. Macmillan Publishing, New York, USA.

Martinez Nieto L., Garrido Hoyos S.E., Camacho Rubio F., Garcia Pareja M.P. \& Ramos Cormenzana A. (1993) The biological purification of waste products from olive oil extraction. Bioresource Technology 43, 215-219.

Milligan S.R., Khan O. \& Nash M. (1998) Competitive binding of xenobiotic oestrogens to rat alpha-fetoprotein and to sex steroid binding proteins in human and rainbow trout (Oncorhynchus mykiss) plasma. General and Comparative Endocrinology 112, 89-95.

Morell M.K. \& Myers A.M. (2005) Towards the rational design of cereal starches. Current Opinion in Plant Biology 8, 204-210.

Moundras C., Behr S.R., Rémésy C. \& Demigné C. (1997) Fecal losses of sterols and bile acids induced by feeding rats guar gum are due to greater pool size and liver bile acid secretion. Journal of Nutrition 127, 10681076.

Mukhopadhyay N. \& Ray A.K. (1999) Effect of fermentation on the nutritive value of sesame seed meal in the diets for rohu, Labeo rohita (Hamilton), fingerlings. Aquaculture Nutrition 5, 229-236.

Nelson P. \& Delane R. (1990) Producing lupins in Western Australia. In: Bulletin 4176. WA Department of Agriculture. (ed. by E. Lawson). South Perth,Western Australia.

Ng W., Lim H., Lim S. \& Ibrahim C. (2002) Nutritive value of palm kernel meal pretreated with enzyme or fermented with Trichoderma kongii (Oudemans) as a dietary ingredient for red hybrid tilapia (Oreochromis sp.). Aquaculture Research 33, 1199-1207.

NRC. (1993) Nutrient Requirements of Fish. Natioal Research Council. National Academy Press, Washington, DC, USA, $114 \mathrm{pp}$.

NRC. (1994) Nutrient Requirements of Poultry. National Research Council. National Academy Press, Washington, DC, USA, 155pp. 
NRC. (1998) Nutrient Requirements of Swine. National Research Council. National Academy Press, Washington, DC, USA, 189pp.

Oda K., Matsuda H., Murakami T., Katayama S., Ohgitani T. \& Yoshikawa M. (2003) Relationship between adjuvant activity and amphipathic structure of soyasaponins. Vaccine 21, 2145-2151.

Okot-Kotber M., Yong K.J., Bagorogoza K. \& Liavoga A. (2003) Phytase activity in extracts of flour and bran from wheat cultivars: enhanced extractability with [b]-glucanase and endo-xylanase. Journal of Cereal Science 38, 307-315.

Olli J.J. \& Krogdahl A. (1994) Nutritive value of four soybean products as protein sources in diets for rainbow trout (Oncorhynhcus mykiss, Walbaum) reared in fresh water. Acta Agriculturae Scandinavica 44, 185-192.

Olli J.J., Hjelmeland K. \& Krogdahl Å. (1994) Soybean trypsin inhibitors in diets for Atlantic salmon (Salmo salar, L): effects on nutrient digestibilities and trypsin in pyloric caeca homogenate and intestinal content. Comparative Biochemistry and Physiology 109A, 923-928.

Olli J.J., Krogdahl Å., van dan Ingh T.S.G.A.M. \& Brattås L.E. (1994) Nutritive value of four soybean products in diets for Atlantic salmon (Salmo salar, L.). Acta Agriculturae Scandinavica Section A, Animal Science 44, 50-60.

Olsen R.E., Myklebust R., Kryvi H., Mayhew T.M. \& Ringo E. (2001) Damaging effect of dietary inulin on intestinal enterocytes in Arctic charr (Salvelinus alpinus L.). Aquaculture Research 32, 931-934.

Overturf K., Raboy V., Cheng Z.J. \& Hardy R.W. (2003) Mineral availability from barley low phytic acid grains in rainbow trout (Oncorhynchus mykiss) diets. Aquaculture Nutrition 9, 239-246.

Overturf K., Bullock D., LaPatra S. \& Hardy R. (2004) Genetic selection and molecular analysis of domesticated rainbow trout for enhanced growth on alternative diet sources. Environmental Biology of Fishes 69, 409-418.

Pelissero C., LeMenn F. \& Kaushick S. (1991) Estrogenic effect of dietary soya bean meal on vitellogenesis in cultured Siberian sturgeon Acipenser baeri. General and Comparative Endocrinology 83, 447-457.

Pelissero C., Bennetau B., Babin P., LeMenn F. \& Dunogues J. (1991) The estrogenic activity of certain phytoestrogens in the Siberian sturgeon Acipenser baeri. Journal of Steroid Biochemistry and Molecular Biology 38, 293-299.

Pezzato L.E., deOliveira A.C.B., Dias E., Barros M.M. \& Pezzato A.C. (2004) Weight gain and anatomopathological disturbs on Nile tilapia fed with cocoa meal. Pesquisa Agropecuaria Brasileira 31, 375-378.

Piskula M.K. \& Terao J. (1998) Accumulation of ( - )-epicatechin metabolites in rat plasma after oral administration and distribution of conjugation enzymes in rat tissues. Journal of Nutrition 128, 1172-1178.

Plakas S.M., Lee T.-C. \& Wolke R.E. (1985) Absence of overt toxicity from feeding the flavonol, quercetin, to rainbow trout (Salmo gairdneri). Food and Chemical Toxicology 23, 1077-1080.
Pollack S.J., Ottinger M.A., Sullivan C.V. \& Woods L.C. III. (2003) The effects of the soy isoflavone genistein on the reproductive development of striped bass. North American Journal of Aquaculture 65, 226-234.

Pomeranz Y., Carvajal M.I., Hoseney R.C. \& Ward A.B. (1970) Wheat germ in bread making. I. Composition of germ lipids and germ protein fractions. Cereal Chemistry 47, 373-380.

Raboy V. \& Dickinson D.B. (1993) Phytic acid levels in seeds of Glycine $\max$ and G. soja as influenced by phosphorus status. Crop Science 33, 1300-1305.

Refstie S., Storebakken T. \& Roem A.J. (1998) Feed consumption and conversion in Atlantic salmon (Salmo salar) fed diets with fish meal, extracted soybean meal or soybean meal with reduced content of oligosaccharides, trypsin inhibitors, lectins and soy antigens. Aquaculture $\mathbf{1 6 2}$, 301-312.

Refstie S., Svihus B., Shearer K.D. \& Storebakken T. (1999) Nutrient digestibility in Atlantic salmon and broiler chickens related to viscosity and non-starch polysaccharide content in different soyabean products. Animal Feed Science and Technology 79, 331-345.

Refstie S., Sahlstrom S., Brathen E., Baeverfjord G. \& Krogedal P. (2005) Lactic acid fermentation eliminates indigestible carbohydrates and antinutritional factors in soybean meal for Atlantic salmon (Salmo salar). Aquaculture 246, 331-345.

Riche M. \& Brown P.B. (1996) Availability of phosphorus from feedstuffs fed to rainbow trout Oncorhynchus mykiss. Aquaculture 142, 269-282.

Rinchard J., Mbahinzireki G., Dabrowski K., Lee K.-J., Garcia-Abiado M.A. \& Ottobre J.S. (2002) Effects of dietary cottonseed meal protein level on growth, gonad development and plasma sex steroid hormones of tropical fish tilapia, Oreochromis sp. Aquaculture International 10, 11-28.

Rinchard J., Lee K.J., Czesny S., Ciereszko A. \& Dabrowski K. (2003) Effect of feeding cottonseed meal-containing diets to broodstock rainbow trout and their impact on the growth of their progenies. Aquaculture 227, 77-87.

Robinson E.H. \& Li M.H. (1994) Use of plant proteins in catfish feeds: replacement of soybean meal with cottonseed meal and replacement of fish meal with soybean meal and cottonseed meal. Journal of the World Aquaculture Society 25, 271-276.

Robinson E.H. \& TierschT.R. (1995) Effects of long-term feeding of cottonseed meal on growth, testis development, and sperm motility of male channel catfish Ictalurus punctatus broodfish. Journal of the World Aquaculture Society 26, 426-431.

Roche J.R., Kolver E.S., de Veth M.J. \& Napper A. (2001) Diet and genotype affect plasma calcium, magnesium and phosphorus concentrations in the periparturient cow. Proceedings of the New Zealand Society of Animal Production 61, 168-171.

Rohloff J. (2003) Cultivation of Herbs and Medicinal Plants in Norway - Essential Oil Production and Quality Control. The 
Plant Biocentre, Department of Biology, Faculty of Natural Sciences and Technology, Norwegian University of Science and Technology (NTNU), Trondheim, Norway 89pp, ISBN 82-471-5177-4.

Rohloff J. (2004) Essential oil drugs - terpene composition of aromatic herbs. In: Production Practices and Quality Assessment of Food Crops. Vol. 3: Quality Handling and Evaluation (ed. by R. Dris \& S.M. Jain), pp. 73-128. Kluwer Academic Publishers, Dordrecht, the Netherlands.

Roy P.K., Munshi J.D. \& Dutta H.M. (1990) Effect of saponin extracts on morpho-histology and respiratory physiology of an air-breathing fish, Heteropneustes Fossilis (Bloch). Journal of Freshwater Biology 2, 135-145.

Russett C. (2002) Soy Protein Concentrates for Animal Feeds. Animal Nutrition Research Notes. The Solae. SPC-T-47, Fort Wayne, IN, 12 pp.

Sealey W.M. \& Gatlin D.M. III (1999) Overview of nutritional strategies affecting health of marine fish. Journal of Applied Aquaculture 9, 11-26.

Shahidi F. \& Naczk M. (1995) Food Phenolics. Technomic Publishing Co. Lancaster, PA, 331 pp.

Sklan D., Prag T. \& Lupatsch I. (2004) Apparent digestibility coefficients of feed ingredients and their prediction in diets for tilapia Oreochromis niloticus $\times$ Oreochromis aureus (Teleostei, Cichlidae). Aquaculture Research 35 , 358-364.

Skrede G., Storebakken T., Skrede A., Sahlstrom S., Sorensen M., Shearer K.D. \& Slinde E. (2002) Lactic acid fermentation of wheat and barley whole meal flours improves digestibility of nutrients and energy in Atlantic Salmon (Salmo salar L.) diets. Aquaculture 210, 305-321.

Souza E., Tyler J.M., Kephart K.D. \& Kruk M. (1993) Genetic improvement in milling and baking quality of hard red spring wheat cultivars. Cereal Chemistry 70, 280-285.

Stepansky A., Yao Y.,Tang G. \& Galili G. (2004) Regulation of lysine catabolism in Arabidopsis through concertedly regulated synthesis of the two distinct gene products of the composite ATLKR/SDH locus. Journal of Experimental Botany 56, 525-536.

Stickney R.R. \& Shumway S.E. (1974) Occurrence of cellulase activity in the stomachs of fishes. Journal of Fish Biology 6, 779-790.

Storebakken T. (1985) Binders in fish feeds I. Effect of alginate and guar gum on growth, digestibility, feed intake and passage through the gastrointestinal tract of rainbow trout. Aquaculture 47, 11-26.

Storebakken T. \& Austreng E. (1987) Binders in fish feeds II. Effect of different alginates on the digestibility of macronutrients in rainbow trout. Aquaculture 60, 121-131.

Storebakken T., Kvien I.S., Shearer K.D., Grisdale-Helland B., Helland S.J. \& Berge G.M. (1998) The apparent digestibility of diets containing fish meal, soybean meal or bacterial meal fed to Atlantic salmon (Salmo salar): evaluation of different faecal collection methods. Aquaculture 169, 195-210.
Storebakken T., Refstie S. \& Ruyter B. (2000) Soy products as fat and protein sources in fish feeds for intensive aquaculture. In: Soy in Animal Nutrition (ed. by J.K. Drackley), pp. 127-170. Federated Animal Science Society, Savoy, IL, USA.

Sugiura S.H., Dong F.M., Rathbone K.C. \& Hardy R.W. (1998) Apparent protein digestibility and mineral availabilities in various feed ingredients for salmonid feeds. Aquaculture 159, 177-202.

Sugiura S.H., Raboy V., Young K.A., Dong F.M. \& Hardy R.W. (1999) Availability of phosphorus and trace elements in low-phytate varieties of barley and corn for rainbow trout (Oncorhynchus mykiss). Aquaculture 170, 285-296.

Takagi S., Shimeno S., Hosokawa H. \& Ukawa M. (2001) Effect of lysine and methionine supplementation to a soy protein concentrate diet for red sea bream Pagrus major. Fisheries Science 67, 1088-1096.

Takeuchi T. (2001) A review of feed development for early life stages of marine finfish in Japan. Aquaculture 200, 203-222.

Thiessen D.L., Campbell G.L. \& Adelizi P.D. (2003) Digestibility and growth performance of juvenile rainbow trout (Oncorhynchus mykiss) fed with pea and canola products. Aquaculture Nutrition 9, 67-75.

Thiessen D.L., Campbell G.L. \& Tyler R.T. (2003) Utilization of thin distillers solubles as a palatability enhancer in rainbow trout (Oncorhynchus mykiss) diets containing canola meal or air-classified pea protein. Aquaculture Nutrition 9, 1-10.

Tollefsen K.E., Ovrevik J. \& Stenersen J. (2004) Binding of xenoestrogens to the sex steroid-finding protein in plasma from Arctic charr (Salvelinus alpinus L.). Comparative Biochemistry Physiolology 139 (C), 127-133.

Twibell R.G. \& Wilson R.P. (2004) Preliminary evidence that cholesterol improves growth and feed intake of soybean meal-based diets in aquaria studies with juvenile channel catfish, Ictalurus punctatus. Aquaculture 236, 539-546.

Tzchori I., Degani G., Elisha R., Eliyahu R., Hurvitz A., Vaya J. \& Moav B. (2004) The influence of phytoestrogens and oestradiol-17 $\beta$ on growth and sex determination in the European eel (Anguilla anguilla). Aquaculture Research 35 , 1213-1219.

Ulloa J.B., van Weerd J.H., Huisman E.A. \& Verret J.A.J. (2004) Tropical agricultural residues and their potential uses in fish feeds: the Costa Rican situation. Waste Management 24, 87-97.

USDA-National Agricultural Statistics Service. (2005) http://www.nass.usda.gov.

Venou B., Alexis M.N., Fountoulaki E., Nengas I., Apostolopoulou M. \& Castritsi-Cathariou I. (2003) Effect of extrusion of wheat and corn on gilthead sea bream (Sparus aurata) growth, nutrient utilization efficiency, rates of gastric evacuation and digestive enzyme activities. Aquaculture 225, 207-223.

Vivas M., Sanchez-Vazquez F.J., Garcia G. \& Madrid J.A. (2003) Macronutrient self-selection in European sea bass 
in response to dietary protein or fat restriction. Aquaculture Research 34, 271-280.

Wahstrom A.,Tauson R. \& Elwinger K. (1998) Effects on plumage condition, health and mortality of dietary oats/ wheat ratios to three hybrids of laying hens in different housing systems. Acta Agriculturae Scandinavica A, Animal Science 48, 250-259.

Waldroup P.W. \& Smith K.J. (1989) Animal feed uses of legumes. In: Legumes Chemistry, Technology and Human Nutrition (ed. by R.H. Matthews), Marcel Dekker, New York.

Weber L.P., Kiparissis Y., Hwang G.S., Niimi A.J., Janz D.M. \& Metcalfe C.D. (2002) Increased cellular apoptosis after chronic aqueous exposure to nonylphenol and quercetin in adult medaka (Oryzias latipes). Comparative Biochemistry and Physiology Part C: Toxicology and Pharmacology 131, 51-59.

Wilkes G.J., Conte E.D., Yonkyoung K., Holcomb M., Sutherland J.B. \& Miller D.W. (2000) Sample preparation for the analysis of flavours and off-flavours in foods. Journal of Chromatography 880A, 3-33.

Wilson R.P. (2002) Amino acids and proteins. In: Fish Nutrition (ed. by J.E. Halver \& R.W. Hardy), 3rd edn, pp. 144-181. Academic Press, New York, NY, USA.

Wittig J., Herderich M., Graefe E.U. \& Veit M. (2001) Identification of quercetin glucuronides in human plasma by high-performance liquid chromatography-tandem mass spectrometry. Journal of Chromatography B: Biomedical Sciences and Applications 753, 237-243.

Yamamori M., Fujita S., Hayakawa K. \& Matsuki J. (2000) Genetic elimination of a starch granule protein, SGP-1, of wheat generates an altered starch with apparent high amylose. Theoretical and Applied Genetics 101, 21-29.

Yamamoto T., Shima T., Furuita H. \& Suzuki N. (2002) Influence of feeding diets with and without fish meal by hand and by self-feeders on feed intake, growth and nutrient utilization of juvenile rainbow trout (Oncorhynchus mykiss). Aquaculture 214, 289-305. 